Article

\title{
Efficiency of Polder Modernization for Flood Protection. Case Study of Golina Polder (Poland)
}

\author{
Ireneusz Laks *(D) and Zbigniew Walczak $\mathbb{D}$ \\ Institute of Construction and Geoengineering, Poznan University of Life Sciences, 60-637 Poznań, Poland; \\ zbw@up.poznan.pl \\ * Correspondence: ilaks@up.poznan.pl; Tel.: +48-6-1846-6410; Fax: +48-6-1846-6402
}

Received: 27 August 2020; Accepted: 26 September 2020; Published: 29 September 2020

\begin{abstract}
This paper presents an analysis of the effectiveness of variants of the reconstruction of a polder, which is part of the flood protection system of a large urban agglomeration. The Golina polder, located in the floodplain of the Warta River, was selected as the case study. The multi-criteria decision support methods AHP and Fuzzy AHP were used to assess the effectiveness of individual variants. Information on the floods from 1997 and 2010, data on land cover, land development, nature and historical objects were used to estimate the value of the coefficients for the multi-criteria decision methods. It was shown that the planned deep modernization of the hydrotechnical infrastructure and the purchase of land in the polder area is less effective than maintaining the current state of development of the polder.
\end{abstract}

Keywords: polder; multi-criteria decision support; MCDA; MCDM; AHP; Fuzzy AHP; flood protection system

\section{Introduction}

The construction of new hydrotechnical facilities or their modernization usually requires substantial financial expenditures and involves significant interference in the natural environment; thus, it often affects the living conditions of local communities. This applies in particular to large-scale facilities, such as multi-functional retention reservoirs or controllable flood retention areas. Considering hydrotechnical facilities, specifically the ones related to flood protection, decisions are often made after a flood occurs, when there is a lot of social pressure. The pressure is frequently reinforced by the opinions of people who are not knowledgeable, but have, however, a strong influence over local populations. Consequently, this leads to making arbitrary decisions on the spur of the moment, with emotions that sometimes result in ineffective spending of significant sums, usually public money, also affecting large areas. Carrying out investment in the field of effective flood protection requires a detailed analysis of its effectiveness in all technical, economic, ecological and social aspects. This requires the use of advanced methodologies of multi-criteria decision support.

Multi Criteria Decision-making (MCDM)/Multi Criteria Decision Analysis (MCDA) is a set of methods and mathematical solutions, which, based on designated, often contradictory criteria, allows for comparing decision-making variants. The advantages of MCDA methods include ease of solving problems described by various measures; assessment of both qualitative and quantitative factors; and the possibility of taking into account the participation of interested parties, citizens and decision-makers throughout the decision-making process, from contributions to defining solution variants, through selecting criteria and determining preferences, to indicating the final solution. The disadvantages of MCDA include the time-consuming nature of the process due to its great potential for public involvement, repeated subjectivity in assigning weights to individual criteria by experts, which may lead to different solutions obtained by different people depending on the priorities 
indicated by them as important [1,2]. One of the most frequently used methods among MCDAs is AHP-Analytic Hierarchy Process [3,4]. As commonly used in numerous optimization tasks, it has also found use in planning, assessing and managing of flood risk [5-9]. It is often indicated to be one of the most appropriate methods of flood risk assessment [10], with the use of GIS-tools (GIS-MCDA) for developing flood hazard maps [11] or selecting the location of dams [12], also in combination with other methods [13].

The division of a decision-making problem into individual criteria and sub-criteria makes it easier for experts to develop a pairwise comparison matrix that determines the preferences of decision-makers. An alternative approach could be the use of the concept of fuzzy set theory and employing Fuzzy AHP instead [14,15]. Rather than explicitly stated, defined values, Fuzzy AHP uses a range of values to accommodate the uncertainty of decision-makers. The literature offers numerous approaches to the fuzzification of Analytic Hierarchy Process [16,17], which differ, inter alia, in various fuzziness functions, i.e., the most commonly used are triangular, but trapezoidal [18] and spherical are also applied [19]. The analyses presented in [20] show that in Fuzzy AHP the uncertainty levels of the factor do not affect the final decision. From the results, it can be concluded that the rating of the most suitable alternative remains the same, regardless of the factors that cause fuzzification of decision attitudes.

In the examples cited, the main emphasis was placed on retention planning and the optimal use of flood protection systems. The paper's objective is to analyse the impact of adopted technical and legal solutions, taking into account operational, flood safety, ecological, economic and social aspects in the area of flood retention, the terrain currently inhabited and intended for periodic flooding, in relation to the effectiveness of modernization of the Golina polder located in the middle of western part of Poland. The analyses were carried out on the basis of data and information on floods in 1997 and 2010, flood risk maps and flood hazard maps provided by Informatyczny System Osłony Kraju (IT System of the Country's Protection Against Extreme Hazards), numerical simulations from the numerical modelling system [21], numerical terrain models based on LIDAR, as well as expert analyses.

The analysis of polders included in flood protection systems requires, in particular, the use of advanced and reliable numerical models of transient flows of the entire river network [21-23]. They allow for an objective assessment of the impact of modernization works on hydrotechnical facilities on the transformation of flood waves. It is worth noting that changes in the ways of using polders, changes in the plant structure, may significantly affect, also in the future, the flows and flood plains, and the phenomena of sedimentation [24].

The main paper's objective is to analyse the effectiveness of modernization of the Golina polder located in the middle of the western part of Poland. Technical and legal solutions, operational, flood safety, ecological, economic and social aspects were considered. The analyses were aimed at showing the most optimal solution out of the three considered variants. Data for multi-criteria methods were obtained on basis of information on floods in 1997 and 2010, flood risk maps and flood hazard maps provided by Informatyczny System Osłony Kraju (IT System of the Country's Protection Against Extreme Hazards), numerical simulations from the numerical modeling system [21], numerical terrain models based on LIDAR, as well as expert analyses.

It is worth noting that in the cited papers, the main emphasis was placed on retention planning and the optimal use of flood protection systems, and the analysis of the effectiveness of modernization of a polder has not appeared as a subject of multi-criteria analyses so far.

\section{Materials and Methods}

The main steps of the methodology used are shown in Figure 1. The individual steps are described in detail in the following subsections. 


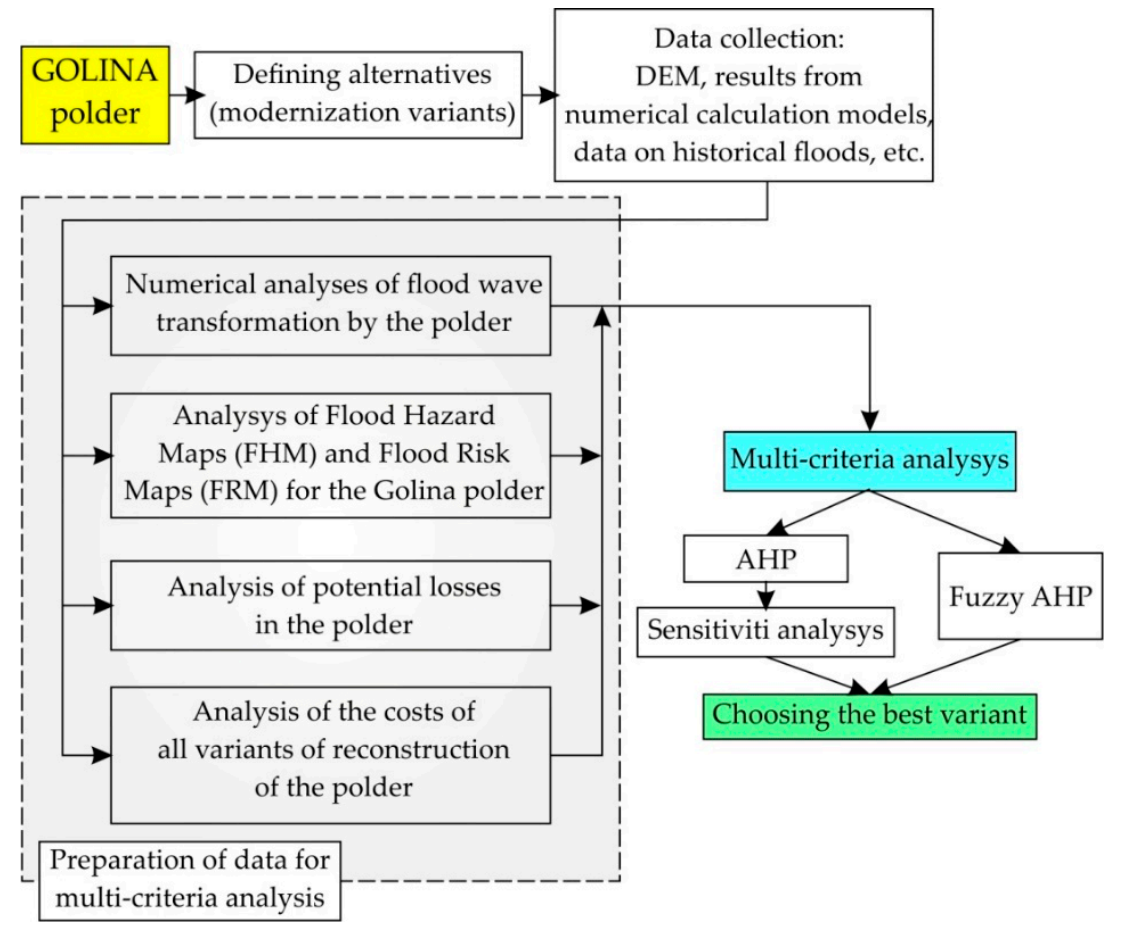

Figure 1. Diagram of the steps of analysis.

\subsection{Description of the Research Object}

The Golina polder (Figure 2) is located in the central part of Poland, on the right bank of the Warta River, below the city of Konin, between $\mathrm{km} 385$ and $\mathrm{km} 398$. The polder was constructed as part of a project to build the widely spread, natural Konin-Pyzdry valley. The complete design of the valley development involved the construction of embankments, which were to divide the valley into nine polders with several hydrotechnical structures (embankment spillways, pumping stations, weirs and sluices). The main task of the designed system was to protect the areas of the lower section of the Warta, particularly the city of Poznań [25].

Limited financial resources and the construction of a large reservoir-Jeziorsko, which reduces the extreme flow rates of the upper section of the river-narrowed significantly the scope of planned works. Finally, for flood protection purposes, the Golina polder was created, with its area intended for agricultural use and optional flood retention. The reservoir is assumed to be non-drained up to the ordinate of threshold of the lower embankment spillway. Above this ordinate, it is a flow-through reservoir filled via the upper spillway and emptied via the lower embankment spillway and the discharge weir (Figure 2). From the north, the polder is bordered by a $10.2 \mathrm{~km}$ long protective embankment and a natural slope that forms the line of the floodplain terrace. From the south, it is bordered by an embankment stretching from the A2 motorway embankment that connects with the terrace slope at $\mathrm{km} 385.5$ of the Warta River. The facility features a discharge weir (three-span with the clearance of $12 \mathrm{~m}$ ) and two embankment spillways of the same length of $200 \mathrm{~m}$, although with different ordinates of their thresholds. The upper spillway is located at $397.5 \mathrm{~km}$, whereas the lower spillway is located at $388.5 \mathrm{~km}$. The polder area is approximately $3055 \mathrm{ha}$, and its static volume up to the ordinates of the threshold of the lower embankment spillway equal to 80 and $49 \mathrm{~m}$ a.s.l. is 25 and $3 \mathrm{mln} \mathrm{m}^{3}$ [21]. 


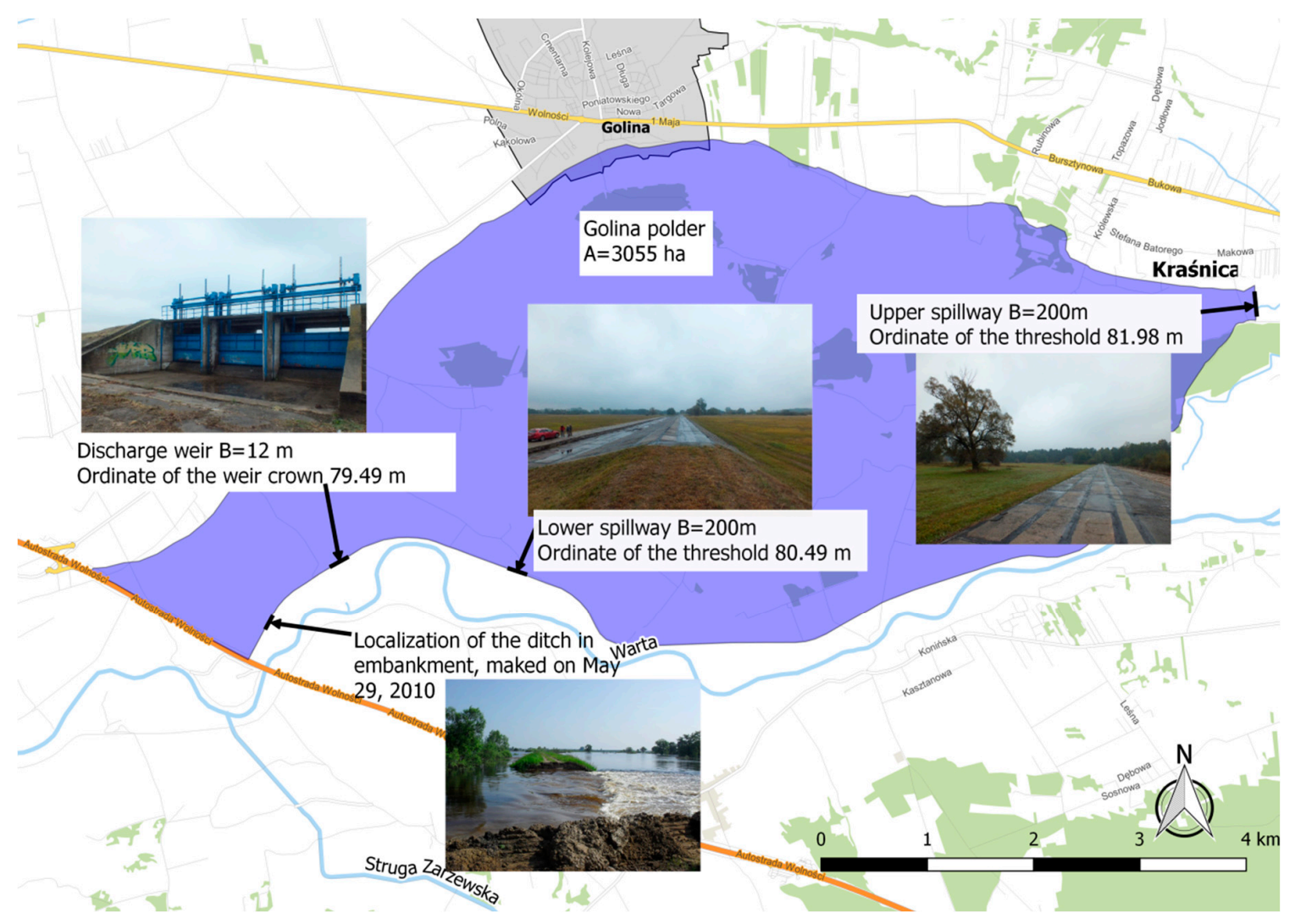

Figure 2. Location of the Golina polder with water facilities within its area.

In the area of the Golina polder, there are 25 villages belonging administratively to three communes of the Konin Poviat. These are Golina, Stare Miasto and Rzgów communes. The largest part of the polder is the commune of Golina covering over $93 \%$, Rzgów commune takes $8.4 \%$, and the smallest is the commune of Stare Miasto, occupying only $0.3 \%$ of the total polder area. The land use structure consists of grassy vegetation, which covers $62.7 \%$ of the total polder area, forests $20.9 \%$, arable land $12.7 \%$, surface waters $2.3 \%$, built-up area $0.8 \%$, other areas $0.1 \%$. Wetlands and rushes constitute $21.1 \%$ of its grassy vegetation. The land use structure reveals significantly the original purpose of the area which now makes the Golina polder. This follows on from previous plans to use it only for pastures and cattle farming.

In the area of the Golina polder there are 355 buildings serving different purposes. The most numerous are farm facilities (234), which constitute $65.9 \%$ of the total number of buildings. The village topology corresponds to the historical layout of settlements that was used in the construction of Olęder farms. It is a linear-row arrangement, which means that the farms are located along main access streets [26]. Within the polder, there are monuments and a cemetery, the remains of the previously mentioned Olęder settlements. The Olęders were a settlement group from the territories of today's Germany and the Netherlands, who, fleeing religious persecution, settled in former Poland. Having practical knowledge of managing wetlands located within flood valleys, they settled in areas that local people did not want or were unable to inhabit and develop.

The percentage of the built-up area on the site is $0.8 \%$, with no unused land. In addition, there are no areas for use whose predestination could have a negative impact on the environment or contribute to the degradation of the land surface (landfills, workings or dumps). The entire polder is located within Natura 2000 protected areas. 


\subsection{The Work of the Golina Polder during the Passage of Flood Waves}

Since the polder was established, there have been two flood waves, in 1997 and 2010, which caused the flooding of the polder area.

During the flood in 1997, the larger part of the Golina polder, i.e., 1732 ha, was flooded. The flood with its extent caused a lot of damage; however, there is no precise data on losses with reference to the event for the Golina polder. Many crops from arable land were damaged, and so were buildings, which—as a result-needed renovation. According to research carried out by the State Inspectorate for Environmental Protection and the Provincial Inspectorate for Environmental Protection in Konin, the flooded area did not deteriorate with regard to the environment as compared to the status before the flood. However, the flood itself led to the first conflict between the residents living in the polder area and the authorities responsible for flood protection. Local population blocked the threshold of the upper embankment spillway with sandbags, preventing the water from flowing to the polder. The same situation also occurred in 2020, as shown in Figure 3.

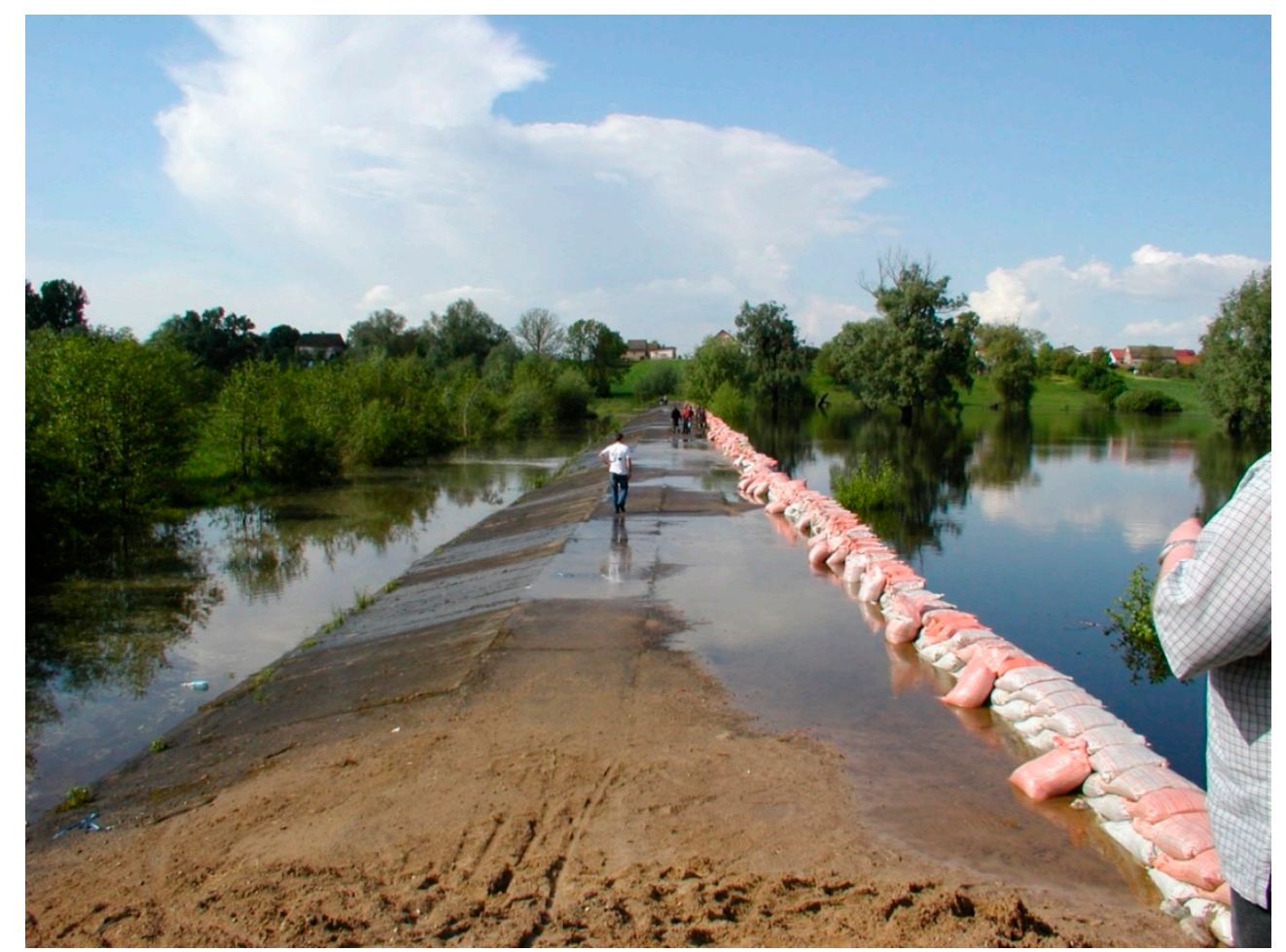

Figure 3. Blocking water with sandbags from flowing to the polder during the flood wave in 2010.

The bags were later removed by the flood service, and part of the polder area was filled with water as intended. According to the analyses carried out by Laks in [21], the polder did not play a significant role in the flood protection system; it was filled to the ordinate of $78.87 \mathrm{~m}$, and the stored volume was 3.9 million $\mathrm{m}^{3}$. Flood peak attenuation through the work of the polder made the flow reduced by $25 \mathrm{~m}^{3} \mathrm{~s}^{-1}$, which was approximately $7.2 \%$ of the total flow of $345 \mathrm{~m}^{3} \mathrm{~s}^{-1}$.

The next flood wave in 2020 caused much greater damage to the polder area and the hydrotechnical infrastructure of the facility. As in 1997, local residents blocked water from flowing to the polder. Most likely, this action contributed to the failure of the upper embankment spillway on 22 May 2020, as shown in Figure 4. 

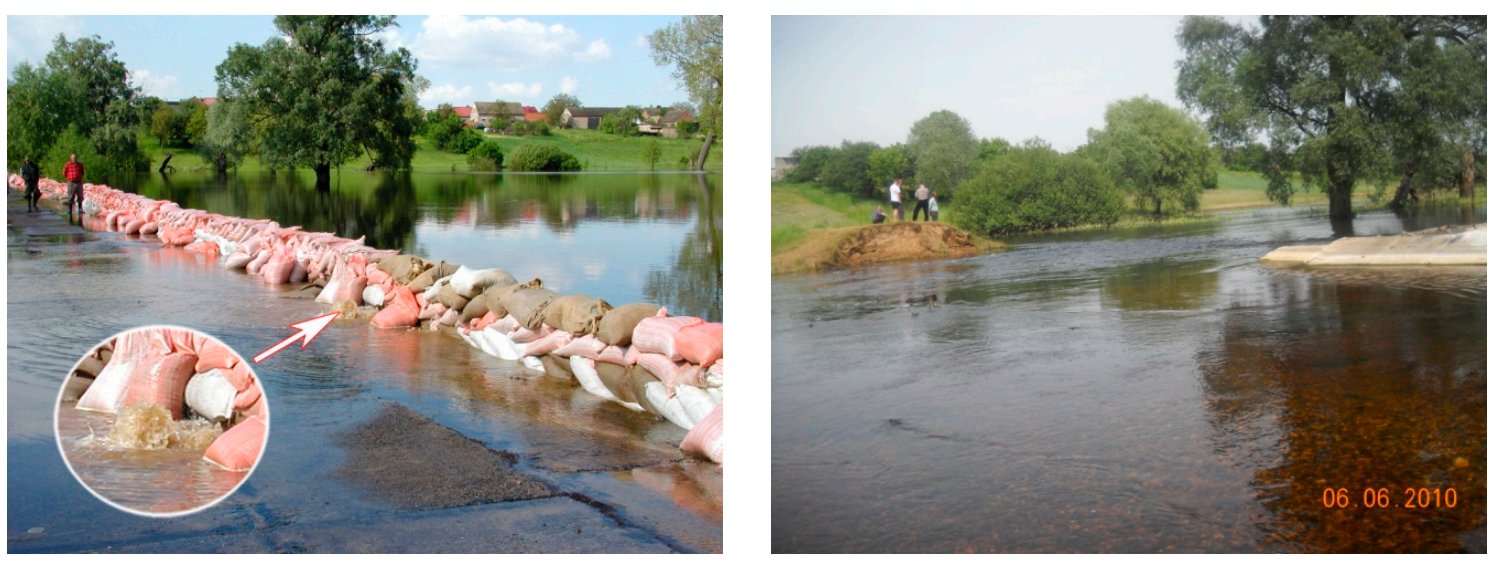

Figure 4. Failure of the upper embankment spillway in Kraśnica in May 2010.

Raising the water table to the level of approximately $0.4 \mathrm{~m}$ above the threshold of the upper embankment spillway led to an increase in the hydraulic gradient, which could cause suffosion of the right abutment and a resultant hydraulic puncture in the threshold. Probably, this part of the embankment spillway had a defectively constructed drainage, which, combined with an increased hydraulic gradient, resulted in the formation of a hydraulic puncture of approximately $23 \mathrm{~m}$ (Figure 4) and uncontrolled flooding of the polder [21]. Due to the risk that the embankment of the A2 motorway, which is part of the structure, would be destroyed, it was decided to make a ditch in the embankment below the discharge weir and drain the excess of retained water (Figure 5). The maximum flow rate to the polder was $56 \mathrm{~m}^{3} \mathrm{~s}^{-1}$, which was $12.2 \%$ of the total flow of $456 \mathrm{~m}^{3} \mathrm{~s}^{-1}$. The polder supported the river through the ditch and the discharge weir with a maximum flow of $68 \mathrm{~m}^{3} \mathrm{~s}^{-1}$ immediately after the ditch was made on 29 May 2010. The maximum flow rate below the polder was $437 \mathrm{~m}^{3} \mathrm{~s}^{-1}$. The actual reduction in the flow rate through the polder was $19 \mathrm{~m}^{3} \mathrm{~s}^{-1}$. According to calculations [21], it delayed the flood wave culmination in the cross section directly below the polder by 3 days (from 26 May to 29 May 2010).

As evidenced by the data obtained from the Commune Office in Golina, five towns were flooded within the area of the Golina polder during the 2010 event: Kolno, Węglewskie Holendry, Myśliborskie Holendry, Bobrowo and Sługocinek. A total of 113 people and 738 animals were evacuated, including 504 cattle, 196 pigs and 38 horses. The total area of the flooded area was approximately 2570 ha, including 2000 ha of meadows and 570 ha of arable land. The road infrastructure was also damaged. The funds granted from the state budget in 2010 to cover losses paid to the victims amounted to PLN 436,252.48 (data obtained from the Wielkopolska Voivodship Office, Department of Safety and Crisis Management). The total sum allocated to cover the losses related to the area and technical infrastructure of the Golina polder amounted to PLN 2,800,000. This high amount was related to the reconstruction of the damaged embankment spillway and repair of the embankment at the site of the ditch. 


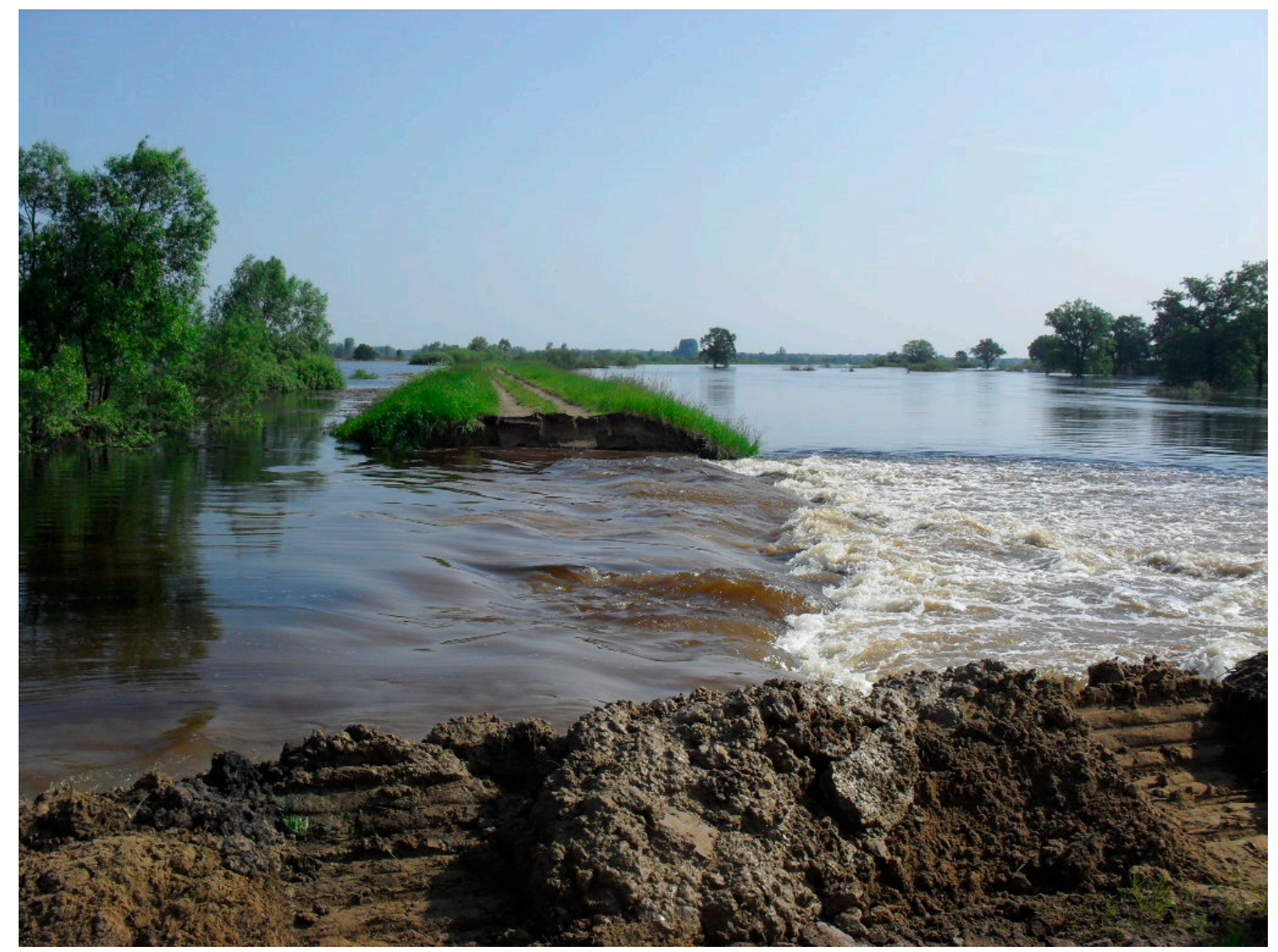

Figure 5. The ditch in the embankment made in order to discharge water from the Golina polder faster after the culmination of the flood wave.

\subsection{Analysis of Potential Losses in the Polder Area on the Basis of Flood Hazard Maps and Flood Risk Maps}

Flood Hazard Maps (FHM) and Flood Risk Maps (FRM) for the Golina polder were developed for flow rates with $\mathrm{HQ}_{10}$ (occurrence once in 10 years), $\mathrm{HQ}_{100}$ (occurrence once in 100 years) and $\mathrm{HQ}_{500}$ (occurrence once in 500 years). The flooding area for $\mathrm{HQ}_{500}$ is $2728.03 \mathrm{ha}$, which is $89 \%$ of the total flooded area of the polder. For $\mathrm{HQ}_{100}$, the flooding area is 2570.89 ha ( $84 \%$ of the tested facility). The smallest area is covered by water that may occur once every 10 years. The flooding area $(1660.65$ ha) constitutes $54 \%$ of the polder area. The area flooded during the flood in 2010 was equal to the area corresponding to $\mathrm{HQ}_{100}$ and in 1997 it was close to $\mathrm{HQ}_{10}$.

By analysing the flood risk maps for the Golina polder, it is possible to estimate the level of losses due to flooding for flood flow rates with different probability of occurrence. Figure 6 shows the percentage share of particular types of land in the total area of the inundation/ flooding for the three above-mentioned flood flow rates. Grassland and arable land constitute the dominant part of the flooded area. For the flow rate with $\mathrm{HQ}_{10}$, there is no flooding of built-up areas and transport routes. The amount of estimated losses is shown in Figure 7. The sum of the forecasted losses ranges from PLN 47,000 for the flood flow rate with $\mathrm{HQ}_{10}$ to PLN 404,000 for the flow rate with $\mathrm{HQ}_{500}$. 


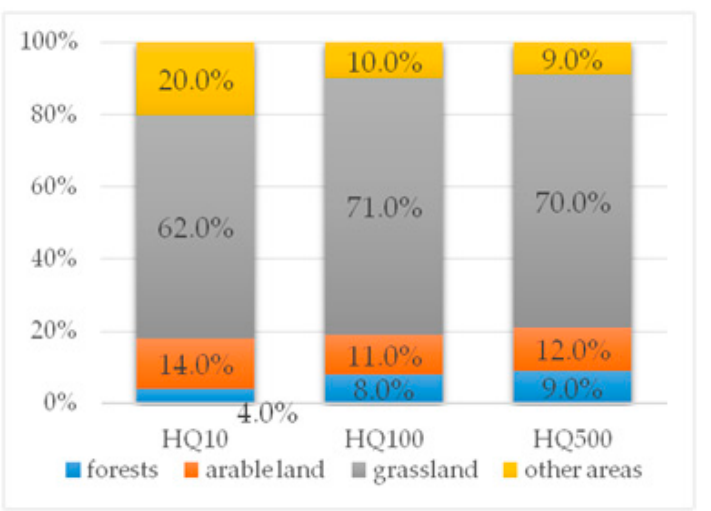

Figure 6. The percentage share of individual types of land in the total flooding area for flood flow rates.

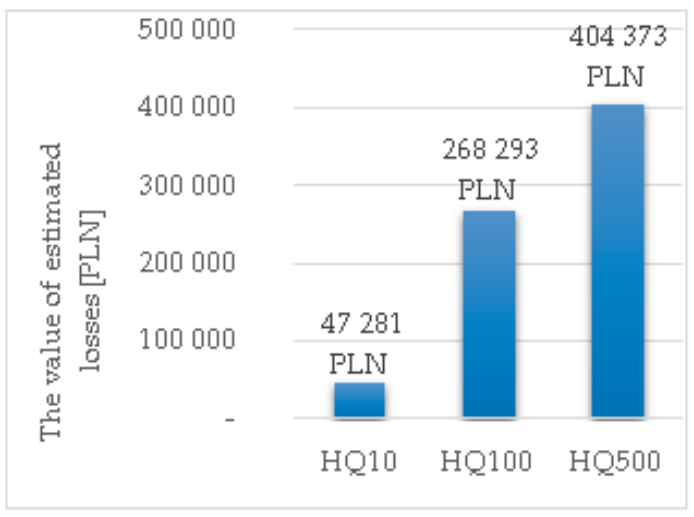

Figure 7. The value of estimated losses for floods with $\mathrm{HQ}_{10}, \mathrm{HQ}_{100}$ and $\mathrm{HQ}_{500}$.

The losses resulting from the 2010 flood were higher than the losses projected for the $\mathrm{HQ}_{500}$ wave, despite the fact that the flow rate was significantly lower. The reason for such high costs was a failure of the embankment spillway and the ditch in the embankment. According to the analyses carried out by Laks [21], if the polder had been used as intended in the management manual, it would have been filled with water to the ordinate of $80.60 \mathrm{~m}$ above sea level, and the area of 2397 ha would have been flooded. This value is close to the value specified on the flood hazard maps for the flow rate $\mathrm{HQ}_{100}(2570 \mathrm{ha})$.

\subsection{Reconstruction Variants of the Golina Polder}

The course of historical floods in the Golina polder shows a conflict of interest between the local community and the services responsible for flood protection. The residents try to hinder water from flowing into the polder area during the passage of the flood wave. They believe that the area should be protected, since the current legal status does not define it as a flood polder. They do not receive any benefits due to the use of their land as part of the flood protection system. On the other hand, state institutions are the owner of the embankments and the hydrotechnical devices that make up the Golina polder. These take care of the proper use of the managed facility during flood waves. The solution to this problem and the formal regulation of the polder's legal status is to purchase the entire area and resettle its residents to areas that are not prone to flooding. There is a project for this solution, which includes:

- purchase of the entire polder area for PLN 180 million,

- reconstruction of the hydrotechnical facilities of the polder-deconstruction of embankment spillways and replacing them with weirs that would enable better control of the polder, 
- construction of an additional embankment separating the polder from the A2 motorway embankment.

This is a basic variant of the Golina polder modernization. The total funds allocated to the polder modernization are estimated at PLN 300 million.

The proposed solution eliminates the cause of disputes with the residents-the entire polder and the hydrotechnical infrastructure would be managed by one owner, i.e., Państwowe Przedsiebiorstwo Wody Polskie. An extended variant of this proposal is to create a retention reservoir in part of the polder area, which would store water for irrigating its adjacent areas. It is worth noting that Wielkopolska, where the polder is located, belongs to the regions with the lowest average annual rainfall in Poland. Water scarcity is increasingly becoming an contributory factor that reduces the productivity of farms.

\subsection{Profitability Analysis of Purchasing the Golina Polder}

The simplest solution to the problem of flood losses and hazards is to evict all residents from flood risk areas and purchase the land. As a result, there would be an uninhabited area intended only for periodic or permanent flooding. It is worth noting, however, that this is not the best possible option in terms of both economic (high costs) and social (natural resistance of the local population who live in this area for a very long time).

The purchase value of the examined facility was determined on the basis of the data from a document developed by a property appraiser for the Golina polder "Preliminary opinion containing approximate values of the real estate". Purchase costs of the entire area were presented for 2015 and were estimated at PLN 180 million. By analysing the data obtained from Państwowe Gospodarstwo Wody Polskie, the average value of one habitat assessed according to the appraisal report is PLN 430,000. Each habitat consists of a residential building and at least two other buildings, which are usually a livestock building or a barn. According to the local residents, the amount estimated by the property appraiser is not equivalent to the value of the habitat and is too low to cover the losses caused by the loss of the farm.

As mentioned earlier, during the flood in 2010, the loss value exceeded PLN 2,800,000 (data obtained from the Department of Safety and Crisis Management of the Wielkopolska Voivodship Office). Assuming that the total amount of losses was fully reimbursed as compensation to land users, which was adopted to simplify calculations, the purchase of the polder by the State is not economically justified. The analysis of hydrological data shows that a flood causing similar losses occurs every 10 years. The amount of PLN 180 million designated for the purchase would only be returned after 600 years.

Financial resources obtained from state institutions mostly cover only basic costs related to repair and renovation after a disaster such as a flood. However, it is not sufficient to restore residential or farm functions of buildings to its pre-flood status. A rational solution is to purchase additional real estate and property insurance. The authors of the study conducted an analysis of the possibility of purchasing additional insurance for real estates and properties located in the Golina polder area, comparing the offers of five popular insurance companies. The offers were compared on the basis of one type of real estate, which is a residential building with related business (farm) located in the village of Wẹglewskie Holendry. The total size of the development was assumed to be $500 \mathrm{~m}^{2}$, and the scope of insurance, constituting the value of the real estate was estimated at PLN 1,000,000. When calculating insurance, most insurers take into account the period since the last damage, which is a flood or inundation, affecting a given real estate/property. The period varies from 3 to 5 years. Above this time range, according to insurers' calculations, the real estate/property is not threatened by random accidents, including flooding. Only two insurance companies are needed to individually calculate an insurance premium due to the location of the real estate in the floodplain area. The obtained data show that the average value of the insurance premium covering flood damage was PLN 830. 
For comparison, an analysis was also made for an object with the same parameters, but not located in the floodplain. The value of the annual premium was PLN 720. This means that the difference in insurance premiums is just over PLN 100. This is the amount that could be refinanced as part of the cost of maintaining the flood protection system.

\subsection{Multi-Criteria Analysis}

The hydrographic, ecological, cultural and social characteristics of the Golina polder area presented above, the analysis of the impact of this facility on the transformation of flood waves, as well as the analysis of actual and potential losses compelled the use of multi-criteria methods to assess the effectiveness of planned reconstruction. Any simplified analysis that ignored one or more factors would not be objective.

Therefore, the analyses used the AHP method [27]. The essence of this process is the division of complex decision-making problems into individual components, thus creating a hierarchical system of dependencies. Elements at a given level of the hierarchy are pairwise compared to assess their relative preferences for each of the elements at the next higher level. The pairwise comparison matrix of sub-criteria for individual groups determines the relative equivalence or domination of the assumed criteria:

$$
B_{k}=\left[\begin{array}{cccc}
1 & b_{12} & \cdots & b_{1 n} \\
1 / b_{12} & 1 & \cdots & b_{2 n} \\
\vdots & \vdots & \vdots & \vdots \\
1 / b_{1 n} & 1 / b_{2 n} & \cdots & 1
\end{array}\right] \text { for } i, j=1,2, \ldots, n
$$

where:

$B_{k}-k$-th pairwise comparison matrix,

$b_{i j}$-aggregation of individual judgements denoting the dominance of $i$-th over $j$-th,

$n$-size of the matrix denoting the number of sub-criteria.

Twenty-five criteria were adopted for the analyses (Table 1). Since developing one large pairwise comparison matrix for the decision-making problem under consideration may be troublesome, even for researchers with extensive experience in this field, the authors proposed to divide criteria within groups and sub-criteria. Six main criteria were identified: social $-G_{1}$, flood safety $-G_{2}$, functional $-G_{3}$, spatial $-\mathrm{G}_{4}$, economic $-\mathrm{G}_{5}$ and ecological $-\mathrm{G}_{6}$.

Table 1. Summary of criteria and adopted rating scales.

\begin{tabular}{|c|c|c|c|}
\hline $\begin{array}{l}\text { Criterion Identifier } \\
\text { and Characteristic }\end{array}$ & Criterion & $\begin{array}{l}\text { Rating } \\
\text { Scale }\end{array}$ & Explanation of the Rating Scale \\
\hline \multicolumn{4}{|c|}{$\mathrm{G}_{1}$-Social } \\
\hline $\begin{array}{c}\text { K1 } \\
\text { destimulant }\end{array}$ & Range of the interested group & $1-3$ & $\begin{array}{l}1 \text {-up to } 20 \% \text { of people living in the polder area } \\
2 \text {-20-60\% } \\
\text { 3-above } 60 \%\end{array}$ \\
\hline $\begin{array}{c}\text { K2 } \\
\text { destimulant }\end{array}$ & Possible social opposition & $1-3$ & $\begin{array}{l}\text { 1-no opposition, } \\
\text { 2-up to } 50 \% \text { of those interested oppose } \\
\text { 3-above } 50 \% \text { of those interested oppose }\end{array}$ \\
\hline $\begin{array}{c}\mathrm{K} 3 \\
\text { stimulant }\end{array}$ & Aesthetics and spatial order & $1-3$ & $\begin{array}{l}\text { 1-the use of the polder will not be preserved } \\
\text { 2-the use of the polder will be partially } \\
\text { preserved } \\
\text { 3-the use of the polder will be fully preserved }\end{array}$ \\
\hline \multirow[t]{2}{*}{$\begin{array}{l}\mathrm{K} 4 \\
\text { stimulant }\end{array}$} & Preservation of cultural heritage & $1-3$ & $\begin{array}{l}\text { 1-completely unpreserved } \\
\text { 2-partially preserved } \\
\text { 3-fully preserved }\end{array}$ \\
\hline & & & $\begin{array}{l}1 \text { - up to } 20 \% \text { of people living in the polder area } \\
2 \text { - } 20-60 \% \\
3 \text {-above } 60 \%\end{array}$ \\
\hline
\end{tabular}


Table 1. Cont.

\begin{tabular}{|c|c|c|c|}
\hline $\begin{array}{l}\text { Criterion Identifier } \\
\text { and Characteristic }\end{array}$ & Criterion & $\begin{array}{l}\text { Rating } \\
\text { Scale }\end{array}$ & Explanation of the Rating Scale \\
\hline \multicolumn{4}{|c|}{$\mathrm{G}_{2}$-Flood safety } \\
\hline $\begin{array}{c}\mathrm{K} 5 \\
\text { stimulant }\end{array}$ & Impact on the adjacent areas & $1-3$ & $\begin{array}{l}\text { Can the work of the polder affect the adjacent } \\
\text { areas? } \\
1 \text {-low impact on improvement in the water } \\
\text { balance } \\
2 \text {-medium impact, slight improvement in the } \\
\text { water balance } \\
3 \text {-high impact, improvement in the water } \\
\text { balance }\end{array}$ \\
\hline $\begin{array}{c}\text { K6 } \\
\text { stimulant }\end{array}$ & Impact on flood peak attenuation & $1-3$ & $\begin{array}{l}\text { 1-low } \\
\text { 2-medium } \\
\text { 3-high }\end{array}$ \\
\hline $\begin{array}{c}\text { K7 } \\
\text { stimulant }\end{array}$ & Control flexibility & $1-3$ & $\begin{array}{l}\text { 1-practically no control flexibility } \\
\text { 2-low flexibility } \\
\text { 3-high flexibility }\end{array}$ \\
\hline $\begin{array}{c}\text { K8 } \\
\text { destimulant }\end{array}$ & $\begin{array}{l}\text { Impact of the human factor on } \\
\text { operational safety }\end{array}$ & $1-2$ & $\begin{array}{l}\text { 1-low } \\
\text { 2-high }\end{array}$ \\
\hline \multicolumn{4}{|c|}{$\mathrm{G}_{3}$-Technical } \\
\hline $\begin{array}{c}\text { K9 } \\
\text { destimulant }\end{array}$ & $\begin{array}{l}\text { Required development of the } \\
\text { technical infrastructure }\end{array}$ & $1-2$ & $\begin{array}{l}\text { 1-none } \\
2 \text {-required development of the infrastructure }\end{array}$ \\
\hline $\begin{array}{c}\text { K10 } \\
\text { destimulant }\end{array}$ & $\begin{array}{l}\text { Required adaptation of the } \\
\text { development to periodical flooding }\end{array}$ & $1-2$ & $\begin{array}{l}\text { 1-none } \\
2 \text {-adaptation required }\end{array}$ \\
\hline $\begin{array}{c}\text { K11 } \\
\text { stimulant }\end{array}$ & Susceptibility to failure & $1-2$ & $\begin{array}{l}\text { 1-high risk of failure } \\
\text { 2-low risk of failure }\end{array}$ \\
\hline \multicolumn{4}{|c|}{$\mathrm{G}_{4}$-Legal } \\
\hline $\begin{array}{c}\text { K12 } \\
\text { stimulant }\end{array}$ & Changes in land ownership & $1-3$ & $\begin{array}{l}\text { 1-applies to every resident within the polder } \\
\text { 2-applies only partially } \\
\text { 3-no need for land ownership changes }\end{array}$ \\
\hline $\begin{array}{c}\text { K13 } \\
\text { stimulant }\end{array}$ & $\begin{array}{l}\text { Claims by farm owners and } \\
\text { entrepreneurs }\end{array}$ & $1-2$ & $\begin{array}{l}\text { 1-none } \\
2 \text {-occurrence of claims }\end{array}$ \\
\hline $\begin{array}{c}\text { K14 } \\
\text { stimulant }\end{array}$ & $\begin{array}{l}\text { Environmental agreements - } \\
\text { approvals }\end{array}$ & $1-2$ & $\begin{array}{l}\text { 1-required environmental approvals } \\
2 \text {-no need to obtain environmental approvals }\end{array}$ \\
\hline $\begin{array}{c}\text { K15 } \\
\text { destimulant }\end{array}$ & $\begin{array}{l}\text { Required adjustment of planning } \\
\text { documents to the change in land } \\
\text { development }\end{array}$ & $1-2$ & $\begin{array}{l}\text { 1-no need to adjust planning documents } \\
2 \text {-necessary adjustment of planning } \\
\text { documents }\end{array}$ \\
\hline \multicolumn{4}{|c|}{$\mathrm{G}_{5}$-Economical } \\
\hline $\begin{array}{c}\text { K16 } \\
\text { destimulant }\end{array}$ & Estimated investment costs & $€$ & \\
\hline $\begin{array}{c}\text { K17 } \\
\text { destimulant }\end{array}$ & $\begin{array}{l}\text { Estimated losses during flood wave } \\
\text { passage }\end{array}$ & $€$ & \\
\hline $\begin{array}{c}\text { K18 } \\
\text { stimulant }\end{array}$ & Estimated investment gains & $€$ & \\
\hline $\begin{array}{c}\text { K19 } \\
\text { destimulant }\end{array}$ & $\begin{array}{l}\text { Providing a source of external } \\
\text { financing }\end{array}$ & $0-2$ & $\begin{array}{l}0 \text {-no possibility of providing a source of } \\
\text { external financing } \\
1 \text {-possibility of providing a source of external } \\
\text { financing up to } 50 \% \\
2 \text { - possibility of providing a source of external } \\
\text { financing above } 50 \%\end{array}$ \\
\hline $\begin{array}{c}\text { K20 } \\
\text { destimulant }\end{array}$ & Operating costs & $€$ & \\
\hline $\begin{array}{c}\text { K21 } \\
\text { destimulant }\end{array}$ & Insurance redemption costs & $€$ & \\
\hline
\end{tabular}


Table 1. Cont.

\begin{tabular}{cccc}
\hline $\begin{array}{c}\text { Criterion Identifier } \\
\text { and Characteristic }\end{array}$ & Criterion & $\begin{array}{c}\text { Rating } \\
\text { Scale }\end{array}$ & Explanation of the Rating Scale \\
\hline $\begin{array}{c}\text { K22 } \\
\text { stimulant }\end{array}$ & Change in biodiversity & $1-2$ & $\begin{array}{l}\text { 1-no changes } \\
\text { 2-change in biodiversity }\end{array}$ \\
\hline $\begin{array}{c}\text { K23 } \\
\text { stimulant }\end{array}$ & Bird habitats & Natura 2000 & $\begin{array}{l}\text { 1-threats to bird habitats } \\
\text { 2-no threats to bird habitats }\end{array}$ \\
\hline $\begin{array}{c}\text { K24 } \\
\text { stimulant }\end{array}$ & 1-2 & $\begin{array}{l}\text { 1-required approvals for the change in land } \\
\text { development }\end{array}$ \\
\hline $\begin{array}{l}\text { K25 } \\
\text { stimulant }\end{array}$ & Protests by environmental to obtain approvals \\
organizations & $1-2$ & $\begin{array}{l}\text { 1-possible protests by environmental } \\
\text { organizations } \\
\text { 2-no protests by environmental organizations }\end{array}$ \\
\hline
\end{tabular}

Each identified group was assigned specific sub-criteria, which allowed for a more detailed analysis of the significance of individual criteria in relation to selected variants and presented with the rating scale (Table 1). A multi-level hierarchical structure of the problem was proposed (Figure 8). Such an approach facilitates the development of relations of importance between hierarchy elements by developing a pairwise comparison matrix only within a given branch.

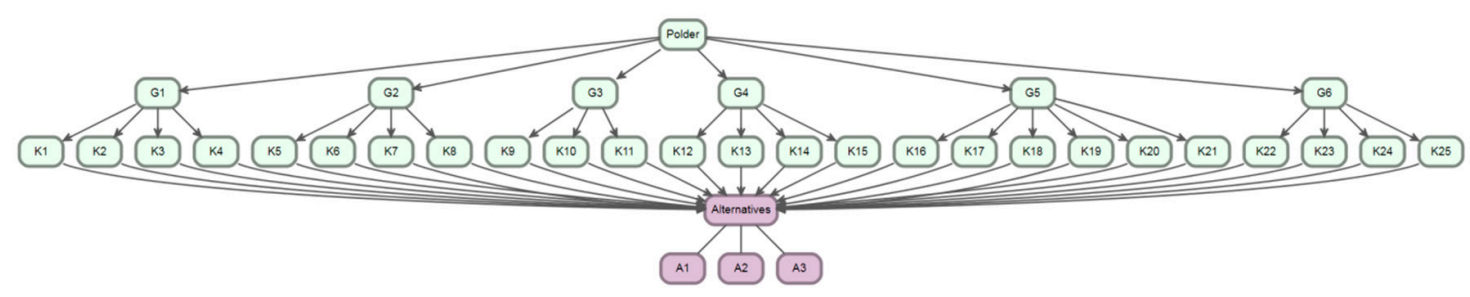

Figure 8. Hierarchical decision tree of the analysed problem.

For all main criteria and sub-criteria paired comparison matrices were developed. Pairwise comparison matrices were constructed using the nine-point rating scale by Saaty [28] (Table 2), first for individual groups, and then for criteria.

Table 2. Relative Saaty's rating scale [28].

\begin{tabular}{cll}
\hline Intensity of Importance & Definition & Explanation \\
\hline 1 & Equal importance & Two elements contribute equally to the objective \\
\hline 3 & Moderate importance & $\begin{array}{l}\text { Experience and judgment slightly favour one } \\
\text { element over another }\end{array}$ \\
\hline 7 & Very strong importance & $\begin{array}{l}\text { One element is favoured very strongly over another, } \\
\text { its dominance is demonstrated in practice }\end{array}$ \\
\hline 9 & Extreme importance & $\begin{array}{l}\text { The evidence favouring one element over another is } \\
\text { of the highest possible order of affirmation }\end{array}$ \\
\hline
\end{tabular}

For each pairwise comparison matrix, the eigenvector vector and the normalized vector of weights were determined, thus obtaining the vectors of local weights for individual criteria $w_{k i}(I=1$ to 25$)$ and the weight vectors for main criteria $w_{G j}(j=1$ to 6$)$. Global preferences $W_{i}$ 一the global vector of weights 
was obtained by multiplying the weights of individual sub-criteria by the weights of the respective criteria groups:

$$
W_{i}=w_{k i} \cdot w_{G j} ; \text { where } w_{k i} \in G_{j}
$$

Consistency ratios (CR) for individual matrices were also estimated:

$$
C R=\frac{C I}{R I}
$$

where:

$$
C I=\frac{\lambda_{\max }-n}{n-1}
$$

$W_{i}$ - the global vector of weights

$\lambda_{\max }$-maximum eigenvalue,

$n$-size of comparison matrices $n \leq 15$,

$w_{k i}$-weights for individual criteria,

RI-Random Index obtained by averaging the CI values of a randomly generated reciprocal matrix (Table 3) [29].

Table 3. The value of Random Index (RI) [24].

\begin{tabular}{ccccccccccccc}
\hline $\boldsymbol{n}$ & $\mathbf{2}$ & $\mathbf{3}$ & $\mathbf{4}$ & $\mathbf{5}$ & $\mathbf{6}$ & $\mathbf{7}$ & $\mathbf{8}$ & $\mathbf{9}$ & $\mathbf{1 0}$ & $\mathbf{1 1}$ & $\mathbf{1 2}$ & $\mathbf{1 3}$ \\
\hline RI & 0.00 & 0.52 & 0.89 & 1.11 & 1.25 & 1.35 & 1.40 & 1.45 & 1.49 & 1.51 & 1.54 & 1.56 \\
\hline
\end{tabular}

The CR values for individual matrices (groups and criteria) should not exceed the acceptable threshold of 0.10 , otherwise the pairwise comparison matrix should be re-analysed.

Individual preferences in matrices were determined with expert methodology using available materials and documentation.

The result of individual variants $R_{A i}$ ( $i$-alternative number) was determined from the dependency:

$$
R_{A_{i}}=\sum_{j=1}^{n} V_{j} \cdot W_{j}
$$

where $V_{j}$-rating values of individual criteria for a given variant; $n$-number of criteria, $W_{j}$-global weight of a given criterion.

The final rating was obtained by arranging the $R_{A_{i}}$ results of individual variants in descending order.

AHP calculations were made using the R program featuring the rStudio graphic interface with the AHPmethod package 0.2.12 [30,31].

\subsection{Fuzzy AHP}

The problem was also analysed using Fuzzy AHP. The fuzzy pairwise comparison matrix was obtained with previously developed pairwise comparison matrices, which were supplemented by adding fuzzy numbers. The triangular fuzzy number $\widetilde{c}=\left(c_{1}, c_{2}, c_{3}\right)$ is determined by triple real numbers $c_{1}, c_{2}, c_{3}$ in the following way [32]:

$$
\mu_{\tilde{c}}(x)=\left\{\begin{array}{cc}
\frac{x-c_{1}}{c_{2}-c_{1}}, & c_{1}<x<c_{2} \\
1, & x=c_{2} \\
\frac{c_{3}-x}{c_{3}-c_{2}}, & c_{2}<x<c_{3} \\
0, & \text { otherwise }
\end{array}\right.
$$


where $c_{1}, c_{2}, c_{3}$ are denominated lower $c_{1}$, middle $c_{2}$, and upper $c_{3}$ significant values where middle values $x$ are equivalent to pairwise comparison matrix values of the normal AHP method. For positive triangular fuzzy numbers $\widetilde{c}=\left(c_{1}, c_{2}, c_{3}\right)$ and $\widetilde{d}=\left(d_{1}, d_{2}, d_{3}\right)$, the following operations are defined: addition, multiplication and divisions $\widetilde{c}+\widetilde{d}=\left(c_{1}+d_{1}, c_{2}+d_{2}, c_{3}+d_{3}\right), \widetilde{c} \cdot \vec{d}=\left(c_{1} \cdot d_{1}, c_{2} \cdot d_{2}, c_{3} \cdot d_{3}\right)$, and $\widetilde{c} / \widetilde{d}=\left(c_{1} / d_{3}, c_{2} / d_{2}, c_{3} / d_{1}\right)$, respectively. The reciprocal of $\widetilde{c}$ is defined as $1 / \widetilde{c}=(1 / \mathrm{c} 3,1 / \mathrm{c} 2,1 / \mathrm{c} 1)$. For $n \in \mathrm{N}, n \geq 2$, the $n$-th root of $\widetilde{c}$ is defined as $\sqrt[n]{c}=\left(\sqrt[n]{c_{1}}, \sqrt[n]{c_{2}}, \sqrt[n]{c_{3}}\right)$. The lower and upper values were generated taking into account the fuzzification factor $\Delta$ in accordance with Table 4 . For the fuzzy pairwise comparison matrix development, the authors adopted a fuzzification factor $\Delta=1$. Seven fuzzy matrices were obtained, consisting of vectors of triangular fuzzy numbers in the form of:

$$
\widetilde{B}_{k}=\left(\widetilde{b}_{i j}\right)_{n \times n}\left[\begin{array}{cccc}
(1,1,1) & \left(l_{12}, m_{12}, u_{12}\right) & \cdots & \left(l_{1 n}, m_{1 n}, u_{1 n}\right) \\
\left(\frac{1}{l} 12, \frac{1}{m_{12}}, \frac{1}{u_{12}}\right) & (1,1,1) & \cdots & \left(l_{2 n}, m_{2 n}, u_{2 n}\right) \\
\vdots & \vdots & \vdots & \vdots \\
\left(\frac{1}{l} l_{1}, \frac{1}{m_{1 n}}, \frac{1}{u_{1 n}}\right) & \left(\frac{1}{l_{2 n}}, \frac{1}{m_{2 n}}, \frac{1}{u_{2 n}}\right) & \cdots 1,1, & (1)
\end{array}\right] \text { for } i, j=1,2, \ldots, n
$$

where: $l_{i j}, m_{i j}$ and $u_{i j}$ are lower, middle, and upper of triangular fuzzy numbers, denoting the dominance of $i$-th over $j$-th.

Table 4. Fuzzy numbers used for making pairwise comparisons [33].

\begin{tabular}{|c|c|c|c|}
\hline Relative Importance & Fuzzy Scale & Definition $^{a}$ & Explanation \\
\hline 1 & $(1,1,1)$ & \multirow{2}{*}{$\begin{array}{l}\text { Equal importance } \\
\text { Weak importance }\end{array}$} & $\begin{array}{l}\text { Two activities contribute equally to } \\
\text { the objective }\end{array}$ \\
\hline 3 & $\left(3-\Delta^{\mathrm{b}}, 3,3+\Delta\right)$ & & favour one activity over another \\
\hline 5 & $(5-\Delta, 5,5+\Delta)$ & $\begin{array}{l}\text { Essential or strong } \\
\text { importance }\end{array}$ & $\begin{array}{l}\text { Experience and judgement strongly } \\
\text { favour one activity over another }\end{array}$ \\
\hline 7 & $(7-\Delta, 7,7+\Delta)$ & $\begin{array}{l}\text { Demonstrated } \\
\text { importance }\end{array}$ & $\begin{array}{l}\text { One activity is strongly favoured } \\
\text { and demonstrated in practice }\end{array}$ \\
\hline 9 & $(8,9,9)$ & Extreme importance & $\begin{array}{l}\text { The evidence favouring one activity } \\
\text { over another is of highest possible } \\
\text { order of affirmation }\end{array}$ \\
\hline $2,4,6,8$ & $(x-\Delta, x, x+\Delta)$ & $\begin{array}{l}\text { Intermediate values } \\
\text { between two } \\
\text { adjacent judgements }\end{array}$ & When compromise is needed \\
\hline $1 / x$ & $(1 /(x+\Delta), 1 / x, 1 /(x-\Delta))$ & & \\
\hline $1 / 9$ & $(1 / 9,1 / 9,1 / 8)$ & & \\
\hline
\end{tabular}

The sum of the middle values of weights is equal to 1 , which is the basic axiom of AHP. The difference between the sum of minimum and maximum values shows a range of uncertainty or fuzziness in the computed weight, and can be viewed as belief and plausibility, respectively [33]. Quality estimation of a pairwise comparison matrix is not a problem in the case of standard AHP. The measure is the consistency ratio (CR). However, a fuzzy matrix consists of vectors of fuzzy numbers and is often inconsistent in nature. Some authors do not verify the consistency of fuzzy pairwise comparison matrices at all [34-36]. Others verify the consistency of fuzzy pairwise comparison matrices only for middle values of the triangular fuzzy numbers from the corresponding fuzzy pairwise comparison matrix $\operatorname{def}(\widetilde{c})=c_{2},[33,36,37]$, following Formula (2). An alternative approach is to make defuzzification of the triangular fuzzy numbers. The literature provides several methods for defuzzification of the triangular fuzzy numbers: defuzzification is done by taking the mean value $[35,38] \operatorname{def}(\widetilde{c})=\left(c_{1}+c_{2}+c_{3}\right) / 3$; the mean value with dominance $[32,39] \operatorname{def}(\widetilde{c})=\left(c_{1}+4 * c_{2}+c_{3}\right) / 6$ 
or based on minimum and maximum values [40]. The most common centroid index method developed by Yager [41,42] is used in this paper:

$$
\operatorname{def}(\widetilde{c})=\frac{\left(c_{2}-c_{1}\right)\left(c_{1}+\frac{2}{3}\left(c_{2}-c_{1}\right)\right)+\left(c_{3}-c_{2}\right)\left(c_{2}+\frac{1}{3}\left(c_{3}-c_{2}\right)\right)}{\left(c_{2}-c_{1}\right)+\left(c_{3}-c_{2}\right)}
$$

The weights $\widetilde{w}_{i}=\left(w_{i 1}, w_{i 2}, w_{i 3}\right)$ of the fuzzy comparison matrix, for each obtained matrix, are calculated by approach described by $[32,43]$ by normalizing the geometric means of the rows of the pairwise comparison matrix:

$$
\begin{aligned}
& w_{i 1}=\min \left\{\frac{\sqrt[p]{\prod_{j=1}^{n} b_{i j}}}{\sum_{k=1}^{p} \sqrt[p]{\prod_{j=1}^{n} b_{i j}}} ; b_{r s} \in\left[b_{r s 1}, b_{r s 3}\right], r, s=1, \ldots, p,\right. \\
& \left.r<s, b_{s r}=\frac{1}{b_{r s}}, r, s=1, \ldots, p, r<s, b_{r r}=1, r=1, \ldots, p\right\}, \\
& w_{i 3}=\frac{\sqrt[p]{\prod_{j=1}^{n} b_{i j 2}}}{\sum_{k=1}^{p}} \sqrt[p]{\prod_{j=1}^{n} b_{i j 2}} \\
& \left.r<s, b_{s r}=\frac{1}{b_{r s}}, r, s=1, \ldots, p, r<s, b_{r r}=1, r=1, \ldots, p\right\} .
\end{aligned}
$$

where: $p$ — the number of $\widetilde{b}_{i j}$ objects on one level of the hierarchy.

There were obtained a total of seven local weight vectors $\widetilde{w}_{i}=\left(w_{i 1}, w_{i 2}, w_{i 3}\right), i=1, \ldots, n$, respectively for the comparison matrix of criteria groups $\widetilde{w}_{G}$ (for $G_{1}-G_{6}$ ) and for individual sub-criteria $\widetilde{w}_{K 1}, \ldots, \widetilde{w}_{K 6}$ (for K1-K25 broken down into particular groups-Table 1). The general weight $\widetilde{u}_{k}=\left(u_{k 1}, u_{k 2}, u_{k 3}\right)$ for the $k$-th criterion was determined as [33]:

$$
\begin{aligned}
& u_{k 1}=w_{k 1} \cdot w_{G 1} ; \text { where } w_{k 1} \in G_{k} \\
& u_{k 2}=w_{k 2} \cdot w_{G 2} ; \text { where } w_{k 2} \in G_{k} \\
& u_{k 3}=w_{k 3} \cdot w_{G 3} ; \text { where } w_{k 3} \in G_{k}
\end{aligned}
$$

Then, the obtained weight vectors were defuzzified using the centroidal method proposed by Yager [42].

The final fuzzy AHP score $\widetilde{F}_{A_{i}}=\left(F_{A_{i} 1}, F_{A_{i} 2}, F_{A_{i} 3}\right), i=1, \ldots, m, m$ - number of alternatives $(m=3)$, for each alternative was designated as:

$$
F_{A_{i}}=\sum_{k=1}^{n} V_{A_{i} k} \cdot u_{k}^{d}
$$

where $V_{A i k}$ is the $k$-th rating (for $k$-th category) for the $i$-th alternative $A_{i}$, whereas $u_{k}^{d}$ is analogously the $k$-th general weight after defuzzification (for the $k$-th category).

The analyses used the FuzzyAHP package for $\mathrm{R}$ [44] to determine the fuzzy pairwise comparison matrix and fuzzy local weights $\widetilde{w}_{i}$ (Equations (7)-(9)). 


\section{Results}

\subsection{Variants}

The analysis covered three variants of economic, technical and legal solutions that could be implemented in the areas of controlled and uncontrolled flood retention.

- Variant 1 (Alternative $\mathrm{A}_{1}$ ) - legal status of the polder area and the technical infrastructure remain unchanged, with a guarantee of covering the costs of additional insurance policies by the State;

- Variant 2 (Alternative $\mathrm{A}_{2}$ ) -reconstruction in accordance with the assumptions described in section "Reconstruction variants of the Golina polder"-a basic variant;

- Variant 3 (Alternative $A_{3}$ ) - reconstruction in accordance with the assumptions described in the section "Reconstruction variants of the Golina polder" — an extended variant.

The conducted analyses made it possible to develop ratings for individual variants/alternatives in relation to the analysed criteria. The ratings were adopted for 100-year-old water $\left(Q_{100}\right)$ and summarized in Table 5.

Table 5. Summary of ratings of individual criteria of the considered variants of land development changes.

\begin{tabular}{|c|c|c|c|c|c|c|}
\hline & \multirow{2}{*}{ Criterion } & \multirow{2}{*}{ Rating Scale } & \multirow{2}{*}{$\mathrm{s} / \mathrm{d}$ * } & \multicolumn{3}{|c|}{ Variant } \\
\hline & & & & $\mathbf{A}_{1}$ & $\mathbf{A}_{2}$ & $\mathbf{A}_{3}$ \\
\hline \multicolumn{7}{|c|}{ Social $\mathrm{G}_{1}-18 \%$} \\
\hline K1 & Range of the interested group & $1-3$ & $\mathrm{~d}$ & 1 & 2 & 3 \\
\hline $\mathrm{K} 2$ & Possible social opposition & $1-3$ & $\mathrm{~d}$ & 1 & 3 & 3 \\
\hline $\mathrm{K} 3$ & Aesthetics and spatial order & $1-3$ & $\mathrm{~s}$ & 3 & 2 & 1 \\
\hline $\mathrm{K} 4$ & Preservation of cultural heritage & $1-3$ & s & 3 & 2 & 1 \\
\hline \multicolumn{7}{|c|}{ Flood safety $\mathrm{G}_{2}-40.7 \%$} \\
\hline K5 & Impact on the adjacent areas & $1-3$ & $\mathrm{~s}$ & 1 & 2 & 3 \\
\hline K6 & Impact on flood peak attenuation & $1-3$ & $\mathrm{~s}$ & 2 & 3 & 3 \\
\hline K7 & Control flexibility & $1-3$ & s & 1 & 3 & 2 \\
\hline K8 & $\begin{array}{l}\text { Impact of the human factor on operational } \\
\text { safety }\end{array}$ & $1-2$ & $\mathrm{~d}$ & 1 & 2 & 2 \\
\hline \multicolumn{7}{|c|}{ Technical $G_{3}-5.7 \%$} \\
\hline K9 & $\begin{array}{l}\text { Required development of the technical } \\
\text { infrastructure }\end{array}$ & $1-2$ & $\mathrm{~d}$ & 1 & 2 & 2 \\
\hline K10 & $\begin{array}{l}\text { Required adaptation of the development to } \\
\text { periodical flooding }\end{array}$ & $1-2$ & $\mathrm{~d}$ & 1 & 2 & 2 \\
\hline K11 & Susceptibility to failure & $1-2$ & $\mathrm{~s}$ & 2 & 1 & 1 \\
\hline \multicolumn{7}{|c|}{ Legal $G_{4}-5.9 \%$} \\
\hline K12 & Changes in land ownership & $1-3$ & $\mathrm{~s}$ & 3 & 2 & 1 \\
\hline K13 & Claims by farm owners and entrepreneurs & $1-2$ & s & 1 & 2 & 2 \\
\hline K14 & Environmental agreements - approvals & $1-2$ & s & 2 & 1 & 1 \\
\hline K15 & $\begin{array}{l}\text { Required adjustment of planning documents } \\
\text { to the change in land development }\end{array}$ & $1-2$ & $\mathrm{~d}$ & 1 & 2 & 2 \\
\hline
\end{tabular}


Table 5. Cont.

\begin{tabular}{|c|c|c|c|c|c|c|}
\hline & \multirow{2}{*}{ Criterion } & \multirow{2}{*}{ Rating Scale } & \multirow{2}{*}{$\mathrm{s} / \mathrm{d}$ * } & \multicolumn{3}{|c|}{ Variant } \\
\hline & & & & $\mathbf{A}_{1}$ & $\mathbf{A}_{2}$ & $\mathbf{A}_{3}$ \\
\hline \multicolumn{7}{|c|}{ Economic $\mathrm{G}_{5}-8.3 \%$} \\
\hline K16 & Estimated investment costs & $€$ & $\mathrm{~d}$ & 0 & $74.4 \mathrm{~m}$ & $80 \mathrm{~m}$ \\
\hline K17 & Estimated losses during flood wave passage & $€$ & $\mathrm{~d}$ & $0.651 \mathrm{~m}$ & 0 & 0 \\
\hline K18 & Estimated investment gains & $€$ & $\mathrm{~s}$ & 0 & $1.95 \mathrm{~m}$ & $1.95 \mathrm{~m}$ \\
\hline K19 & Providing a source of external financing & $0-2$ & $\mathrm{~d}$ & 0 & 1 & 1 \\
\hline K20 & Operating costs & $€$ & d & 15,000 & 30,000 & 45,000 \\
\hline K21 & Insurance redemption costs & $€$ & d & 15,000 & 0 & 0 \\
\hline \multicolumn{7}{|c|}{ Ecological $\mathrm{G}_{6}-21.5 \%$} \\
\hline $\mathrm{K} 22$ & Change in biodiversity & $1-2$ & $\mathrm{~s}$ & 1 & 2 & 2 \\
\hline K23 & Bird habitats & $1-2$ & $\mathrm{~s}$ & 2 & 1 & 1 \\
\hline K24 & Natura 2000 & $1-2$ & $\mathrm{~s}$ & 2 & 1 & 1 \\
\hline K25 & Protests by environmental organizations & $1-2$ & $\mathrm{~s}$ & 2 & 1 & 1 \\
\hline
\end{tabular}

\section{2. $A H P$}

First, the authors analysed the decision-making problem using the standard AHP methodology. They adopted six main groups of criteria, $\mathrm{G}_{1}-\mathrm{G}_{6}$ (Table 1), within which appropriate sub-criteria K1-K25 were assigned, developed pairwise comparison matrices and determined the Consistency Ratio values in accordance with Equation (2) (Tables 6-12).

Table 6. Pairwise comparison matrix for main criteria $G_{1}-G_{6}$.

\begin{tabular}{cccccccc}
\hline & $\mathbf{G}_{\mathbf{1}}$ & $\mathbf{G}_{\mathbf{2}}$ & $\mathbf{G}_{\mathbf{3}}$ & $\mathbf{G}_{\mathbf{4}}$ & $\mathbf{G}_{\mathbf{5}}$ & $\mathbf{G}_{\mathbf{6}}$ & \\
\hline $\mathrm{G}_{1}$ & 1 & $1 / 4$ & 5 & 5 & 1 & 1 & \\
$\mathrm{G}_{2}$ & 4 & 1 & 5 & 4 & 4 & 3 & \\
$\mathrm{G}_{3}$ & $1 / 5$ & $1 / 5$ & 1 & 1 & 1 & $1 / 4$ & $\mathrm{CR}=0.072 ;$ \\
$\mathrm{G}_{4}$ & $1 / 5$ & $1 / 4$ & 1 & 1 & 1 & $1 / 5$ & \\
$\mathrm{G}_{5}$ & 1 & $1 / 4$ & 1 & 1 & 1 & $1 / 4$ & \\
$\mathrm{G}_{6}$ & 1 & $1 / 3$ & 4 & 5 & 4 & 1 & \\
\hline
\end{tabular}

Table 7. Pairwise comparison matrix for sub-criteria K1-K4.

\begin{tabular}{cccccl}
\hline & K1 & K2 & K3 & K4 & \\
\cline { 1 - 4 } K1 & 1 & $1 / 7$ & 1 & $1 / 7$ & \\
$\mathrm{~K} 2$ & 7 & 1 & 5 & 1 & CR $=0.026 ;$ \\
$\mathrm{K} 3$ & 1 & $1 / 5$ & 1 & $1 / 3$ & \\
$\mathrm{~K} 4$ & 7 & 1 & 3 & 1 & \\
\hline
\end{tabular}

Table 8. Pairwise comparison matrix for sub-criteria K5-K8.

\begin{tabular}{cccccc}
\hline & K5 & K6 & K7 & K8 & \\
\cline { 1 - 4 } K5 & 1 & $1 / 5$ & $1 / 5$ & $1 / 3$ & \\
K6 & 5 & 1 & 1 & $1 / 2$ & CR $=0.07 ;$ \\
K7 & 5 & 1 & 1 & $1 / 2$ & \\
K8 & 3 & 2 & 2 & 1 & \\
\hline
\end{tabular}


Table 9. Pairwise comparison matrix for sub-criteria K9-K11.

\begin{tabular}{lcccc}
\hline & K9 & K10 & K11 & \\
\cline { 1 - 4 } K9 & 1 & 1 & $1 / 3$ & \\
K10 & 1 & 1 & $1 / 4$ & CR $=0.004$ \\
K11 & 3 & 4 & 1 & \\
\hline
\end{tabular}

Table 10. Pairwise comparison matrix for sub-criteria K12-K15.

\begin{tabular}{cccccc}
\hline & K12 & K13 & K14 & K15 & \\
\cline { 1 - 4 } K12 & 1 & 1 & 2 & 2 & \\
$\mathrm{~K} 13$ & 1 & 1 & 3 & 5 & CR $=0.03$ \\
$\mathrm{~K} 14$ & $1 / 2$ & $1 / 3$ & 1 & 1 & \\
$\mathrm{~K} 15$ & $1 / 2$ & $1 / 5$ & 1 & 1 & \\
\hline
\end{tabular}

Table 11. Pairwise comparison matrix for sub-criteria K16-K21.

\begin{tabular}{lccccccc}
\hline & K16 & K17 & K18 & K19 & K20 & K21 & \\
\cline { 1 - 5 } K16 & 1 & $1 / 4$ & 1 & $1 / 3$ & $1 / 3$ & 1 & \\
K17 & 4 & 1 & 5 & 3 & 3 & 3 & \\
$\mathrm{~K} 18$ & 1 & $1 / 5$ & 1 & $1 / 2$ & $1 / 3$ & 3 & CR $=0.072$ \\
$\mathrm{~K} 19$ & 3 & $1 / 3$ & 2 & 1 & $1 / 3$ & 1 & \\
$\mathrm{~K} 20$ & 3 & $1 / 3$ & 3 & 3 & 1 & 3 & \\
$\mathrm{~K} 21$ & 1 & $1 / 3$ & $1 / 3$ & 1 & $1 / 3$ & 1 & \\
\hline
\end{tabular}

Table 12. Pairwise comparison matrix for sub-criteria K22-K25

\begin{tabular}{cccccc}
\hline & K22 & K23 & K24 & K25 & \\
\cline { 1 - 4 } K22 & 1 & 1 & 1 & $1 / 2$ & \\
K23 & 1 & 1 & 1 & 1 & CR $=0.023$ \\
K24 & 1 & 1 & 1 & 1 & \\
K25 & 2 & 1 & 1 & 1 & \\
\hline
\end{tabular}

For each pairwise comparison matrix, the normalized weight vector (eigenvalue vector) and global AHP weights were determined (Table 13). AHP calculations were made using the R program featuring the RStudio graphic interface with the AHPmethod package 0.2.12.

Table 13. The vector of global weights of AHP for criteria K1-K25.

\begin{tabular}{ccccccccccccc}
\hline Criterion & K1 & K2 & K3 & K4 & K5 & K6 & K7 & K8 & K9 & K10 & K11 & K12 \\
\hline AHP weight \% & 1.3 & 7.9 & 1.7 & 7.1 & 3 & 10.7 & 10.7 & 16.3 & 1.1 & 1 & 3.6 & 1.8 \\
\hline K13 & K14 & K15 & K16 & K17 & K18 & K19 & K20 & K21 & K22 & K23 & K24 & K25 \\
\hline 2.5 & 0.8 & 0.7 & 0.6 & 3.2 & 0.8 & 1.1 & 1.9 & 0.7 & 4.5 & 5.3 & 5.3 & 6.4 \\
\hline
\end{tabular}

A synthetic summary of the results of AHP is presented in Table 14. 
Table 14. Summary of the results of AHP for individual variants $A_{1}-A_{3}$.

\begin{tabular}{cccccc}
\hline & Weight & $\mathbf{A}_{\mathbf{1}}$ & $\mathbf{A}_{\mathbf{2}}$ & $\mathbf{A}_{\mathbf{3}}$ & Inconsistency \\
\cline { 2 - 6 } Polder & $\mathbf{1 0 0 . 0}$ & $\mathbf{4 0 . 0}$ & $\mathbf{3 1 . 6}$ & $\mathbf{2 8 . 4}$ & $\mathbf{7 . 2 \%}$ \\
\hline $\mathrm{G}_{1}$ & 18.0 & 9.8 & 4.9 & 3.3 & $2.6 \%$ \\
$\mathrm{~K} 1$ & 1.3 & 0.7 & 0.3 & 0.2 & \\
$\mathrm{~K} 2$ & 7.9 & 4.8 & 1.6 & 1.6 & \\
$\mathrm{~K} 3$ & 1.7 & 0.8 & 0.6 & 0.3 & \\
$\mathrm{~K} 4$ & 7.1 & 3.5 & 2.4 & 1.2 & \\
\hline $\mathrm{G}_{2}$ & 40.7 & 13.1 & 14.4 & 13.1 & $7.0 \%$ \\
$\mathrm{~K} 5$ & 3.0 & 0.5 & 1.0 & 1.5 & \\
$\mathrm{~K} 6$ & 10.7 & 2.7 & 4.0 & 4.0 & \\
$\mathrm{~K} 7$ & 10.7 & 1.8 & 5.3 & 3.6 & \\
$\mathrm{~K} 8$ & 16.3 & 8.1 & 4.1 & 4.1 & \\
\hline $\mathrm{G}_{3}$ & 5.7 & 2.8 & 1.4 & 1.6 & $0.9 \%$ \\
$\mathrm{~K} 9$ & 1.1 & 0.6 & 0.3 & 0.3 & \\
$\mathrm{~K} 10$ & 1.0 & 0.4 & 0.2 & 0.4 & \\
$\mathrm{~K} 11$ & 3.6 & 1.8 & 0.9 & 0.9 & \\
\hline $\mathrm{G}_{4}$ & 5.9 & 2.2 & 2.0 & 1.7 & $3.0 \%$ \\
$\mathrm{~K} 12$ & 1.8 & 0.9 & 0.6 & 0.3 & \\
$\mathrm{~K} 13$ & 2.5 & 0.5 & 1.0 & 1.0 & \\
$\mathrm{~K} 14$ & 0.8 & 0.4 & 0.2 & 0.2 & \\
$\mathrm{~K} 15$ & 0.7 & 0.4 & 0.2 & 0.2 & \\
\hline $\mathrm{G}_{5}$ & 8.3 & 2.7 & 2.9 & 2.7 & $7.2 \%$ \\
$\mathrm{~K} 16$ & 0.6 & 0.6 & 0.0 & 0.0 & \\
$\mathrm{~K} 17$ & 3.2 & 0.0 & 1.6 & 1.6 & \\
$\mathrm{~K} 18$ & 0.8 & 0.0 & 0.4 & 0.4 & \\
$\mathrm{~K} 19$ & 1.1 & 1.1 & 0.0 & 0.0 & \\
$\mathrm{~K} 20$ & 1.9 & 1.1 & 0.5 & 0.4 & \\
$\mathrm{~K} 21$ & 0.7 & 0.0 & 0.3 & 0.3 & \\
\hline $\mathrm{G} 6$ & 21.5 & 9.4 & 6.0 & 6.0 & \\
$\mathrm{~K} 22$ & 4.5 & 0.9 & 1.8 & 1.8 & \\
$\mathrm{~K} 23$ & 5.3 & 2.6 & 1.3 & 1.3 & \\
$\mathrm{~K} 24$ & 5.3 & 2.6 & 1.3 & 1.3 & \\
$\mathrm{~K} 25$ & 6.4 & 3.2 & 1.6 & 1.6 & \\
\hline & & & & & \\
\hline
\end{tabular}

The obtained ranking $A_{1} \rightarrow A_{2} \rightarrow A_{3}$ indicates that Variant $A_{1}$ dominates (40\%). The ranking achievement was determined in particular by criteria related to ecology, social issues and flood safety. It should be noted that practically all proposed variants were characterized by a similar ranking (result) with regard to flood safety $\left(\mathrm{G}_{2}\right)$, reaching the level of $13-14.5 \%$. Thus, the ranking achievement was determined by ecological and social criteria, where Variant $\mathrm{A}_{1}$ gained a significant advantage. The authors also performed a model sensitivity analysis. The analysis was performed first by modifying the weight of the group of economic criteria, increasing their share in the analysis from approximately $8 \%$ to approximately $37 \%$. The relevant modifications were therefore limited to modifying the pairwise comparison matrix $\mathrm{G}_{1}-\mathrm{G}_{6}$ (compare Tables 6 and 15; the changes are marked in Table 15). The introduced changes did not affect the consistency ratio and the final ranking (Table 16), i.e., $A_{1} \rightarrow A_{2} \rightarrow A_{3}$. Economic and safety criteria remain the most important, at approximately $37 \%$ and $30 \%$, respectively, and the analysed variants obtained a similar rating of approximately $12 \%$ for economic criteria and $10 \%$ for safety criteria. It should be noted that while the ranking remained unchanged, the difference between the variants decreased. 
Table 15. Fuzzy pairwise comparison matrix $\mathrm{G}_{1}-\mathrm{G}_{6}$.

\begin{tabular}{cccccccc}
\hline & $\mathrm{G}_{\mathbf{1}}$ & $\mathrm{G}_{\mathbf{2}}$ & $\mathrm{G}_{\mathbf{3}}$ & $\mathrm{G}_{\mathbf{4}}$ & $\mathrm{G}_{\mathbf{5}}$ & $\mathrm{G}_{\mathbf{6}}$ & \\
\hline $\mathrm{G}_{1}$ & 1 & $1 / 4$ & 5 & 5 & $1 / 4$ & 1 & \\
$\mathrm{G}_{2}$ & 4 & 1 & 5 & 4 & 1 & 3 & \\
$\mathrm{G}_{3}$ & $1 / 5$ & $1 / 5$ & 1 & 1 & $1 / 9$ & $1 / 4$ & $\mathrm{CR}=0.072 ;$ \\
$\mathrm{G}_{4}$ & $1 / 5$ & $1 / 4$ & 1 & 1 & $1 / 9$ & $1 / 5$ & \\
$\mathrm{G}_{5}$ & 4 & 1 & 9 & 9 & 1 & 4 & \\
$\mathrm{G}_{6}$ & 1 & $1 / 3$ & 4 & 5 & 4 & 1 & \\
\hline
\end{tabular}

Table 16. Summary of the results of AHP for individual variants $A_{1}-A_{3}$, for fuzzy pairwise comparison matrix $\mathrm{G}_{1}-\mathrm{G}_{6}$.

\begin{tabular}{|c|c|c|c|c|c|}
\hline \multirow{2}{*}{ Polder } & Weight & $\mathbf{A}_{1}$ & $\mathbf{A}_{2}$ & $\mathbf{A}_{3}$ & Inconsistency \\
\hline & 100.0 & 37.5 & 32.7 & 29.8 & 4.9 \\
\hline $\mathrm{G}_{1}$ & 12.6 & 6.9 & 3.4 & 2.3 & 2.6 \\
\hline K1 & 0.9 & 0.5 & 0.2 & 0.2 & \\
\hline $\mathrm{K} 2$ & 5.6 & 3.3 & 1.1 & 1.1 & \\
\hline K3 & 1.2 & 0.6 & 0.4 & 0.2 & \\
\hline K4 & 5.0 & 2.5 & 1.7 & 0.8 & \\
\hline $\mathrm{G}_{2}$ & 30.0 & 9.7 & 10.6 & 9.7 & 7.0 \\
\hline $\mathrm{K} 5$ & 2.2 & 0.4 & 0.7 & 1.1 & \\
\hline K6 & 7.9 & 2.0 & 3.0 & 3.0 & \\
\hline K7 & 7.9 & 1.3 & 3.9 & 2.6 & \\
\hline K8 & 12.0 & 6.0 & 3.0 & 3.0 & \\
\hline $\mathrm{G}_{3}$ & 3.7 & 1.8 & 0.9 & 1.0 & 0.9 \\
\hline K9 & 0.7 & 0.4 & 0.2 & 0.2 & \\
\hline K10 & 0.6 & 0.3 & 0.1 & 0.3 & \\
\hline K11 & 2.3 & 1.2 & 0.6 & 0.6 & \\
\hline $\mathrm{G}_{4}$ & 3.8 & 1.4 & 1.3 & 1.1 & 3.0 \\
\hline K12 & 1.2 & 0.6 & 0.4 & 0.2 & \\
\hline K13 & 1.7 & 0.3 & 0.7 & 0.7 & \\
\hline K14 & 0.5 & 0.3 & 0.1 & 0.1 & \\
\hline K15 & 0.5 & 0.2 & 0.1 & 0.1 & \\
\hline $\mathrm{G}_{5}$ & 37.4 & 12.3 & 12.9 & 12.2 & 7.2 \\
\hline K16 & 2.7 & 2.7 & 0.0 & 0.0 & \\
\hline K17 & 14.5 & 0.0 & 7.2 & 7.2 & \\
\hline K18 & 3.7 & 0.0 & 1.8 & 1.8 & \\
\hline K19 & 4.8 & 4.8 & 0.0 & 0.0 & \\
\hline K20 & 8.7 & 4.7 & 2.4 & 1.6 & \\
\hline K21 & 3.0 & 0.0 & 1.5 & 1.5 & \\
\hline $\mathrm{G}_{6}$ & 12.4 & 5.4 & 3.5 & 3.5 & 2.3 \\
\hline K22 & 2.6 & 0.5 & 1.0 & 1.0 & \\
\hline K23 & 3.1 & 1.5 & 0.8 & 0.8 & \\
\hline K24 & 3.1 & 1.5 & 0.8 & 0.8 & \\
\hline K25 & 3.7 & 1.9 & 0.9 & 0.9 & \\
\hline
\end{tabular}

Similarly, the matrix of comparisons with $G_{1}-G_{6}$ pairs was modified for the remaining main criteria. The analysis was carried out by modifying the initial matrix (Table 6) by changing the values of pairwise comparison matrix, so that the selected criterion was the predominant. The matrices were modified in such a way that the $G_{2}$ criterion concerning flood safety was always relevant. For each matrix, the consistency ratios (CR) did not exceed 10\%. 
First, the weight of the $\mathrm{G}_{1}$ - social criterion increased to approximately $51 \%$ (an increase by approximately $33 \%$ ). The $\mathrm{G}_{2}$ criterion was left at around $21 \%$. The adopted significance levels of individual criteria are presented in Figure $9 a$, while the final ranking is presented in Figure $9 b$. The results of the sensitivity analysis indicate that the change in the significance level of the first criterion does not significantly affect the final ranking of alternatives. Variant $\mathrm{A}_{1}$ gains an advantage over the next one in the ranking by 16 percentage points.



(a)

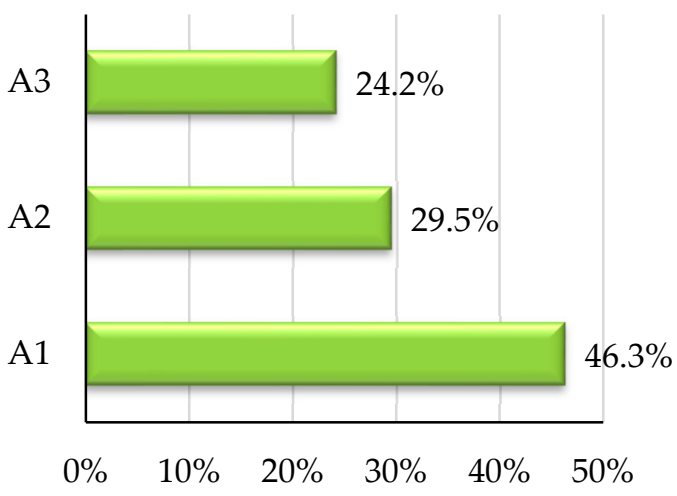

(b)

Figure 9. Scenario $1-\mathrm{G}_{1}$; (a) the significance of the individual criteria; (b) final ranking.

In next step, the significance of the $G_{3}$-technical criterion increased by an appropriate modification of the initial matrix of pairwise comparisons (Table 6). The adopted significance levels of individual criteria are presented in Figure 10a, while the final ranking is presented in Figure 10b. The change in the significance of the $\mathrm{G}_{3}$ criterion by about 46 percentage points did not change the ranking. Variant $A_{1}$ remains the best alternative with an advantage over the other options at the level of 16 percentage points. The variants $A_{2}$ and $A_{3}$ are then equivalent alternatives.

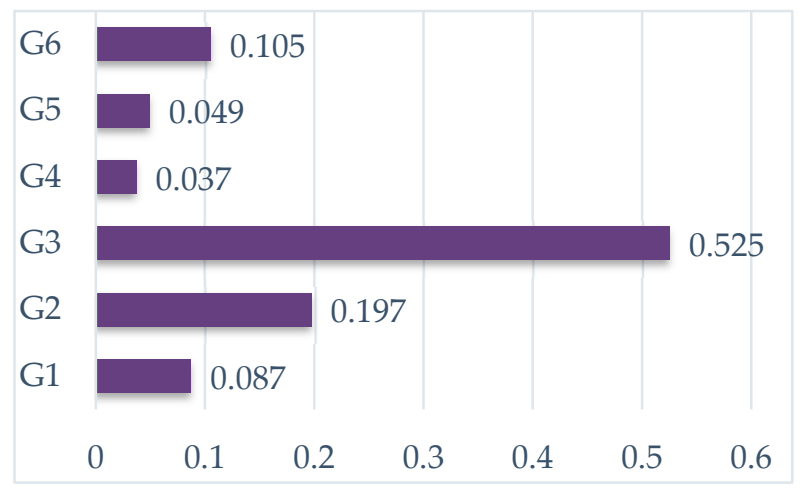

(a)

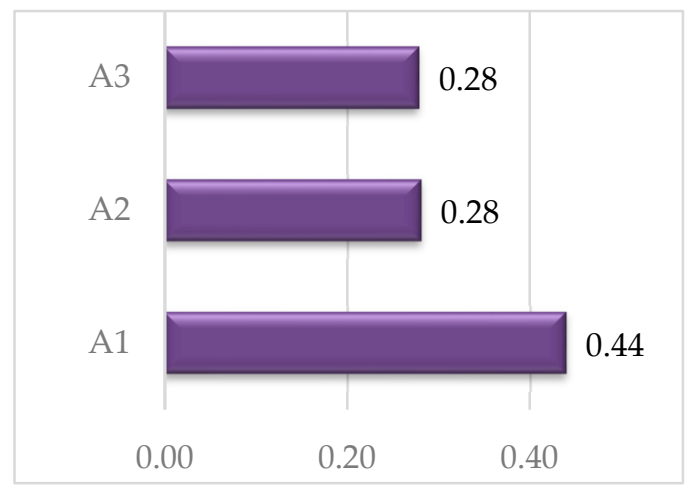

(b)

Figure 10. Scenario $2-\mathrm{G}_{3}$; (a) the significance of the individual criteria; (b) final ranking.

Subsequently, the significance of the $\mathrm{G}_{4}$-legal criterion increased. The adopted significance levels of individual criteria are presented in Figure 11a, while the final ranking is presented in Figure 11b. The change in the significance of the $\mathrm{G}_{4}$ criterion by about 41 percentage points did not change the ranking. The advantage of the $A_{1}$ variant over the other options is definitely smaller, only by 6 percentage points, but still clear. 


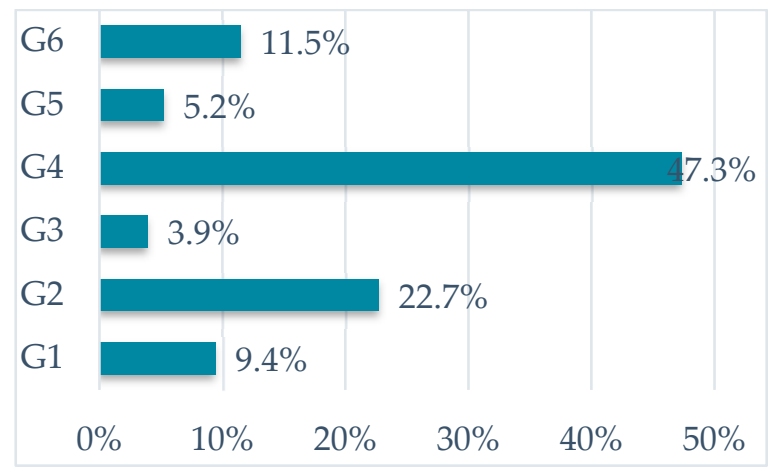

(a)

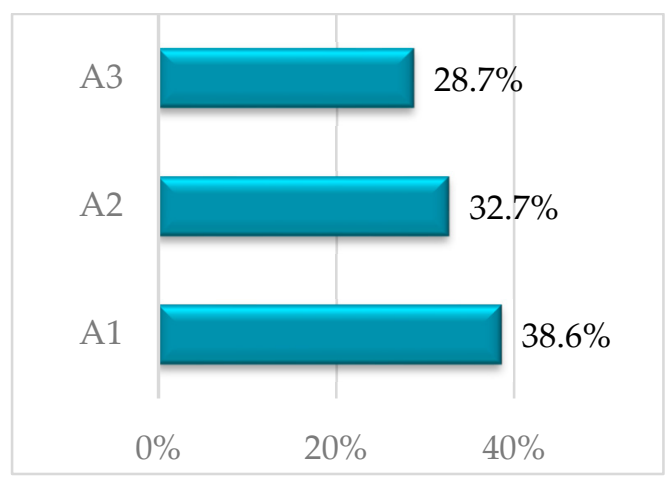

(b)

Figure 11. Scenario $3-\mathrm{G}_{4}$; (a) the significance of the individual criteria; (b) final ranking.

Then, the significance of the $\mathrm{G}_{5}$ - economic criterion was increased. The adopted significance levels of individual criteria are presented in Figure 12a, while the final ranking is presented in Figure 12b. The change in the significance of the $G_{5}$ criterion by about 30 percentage points also did not change the ranking. As in the case of the dominance of the $G_{4}$ criterion, the advantage of variant $A_{1}$ is definitely smaller, by only 5 percentage points.

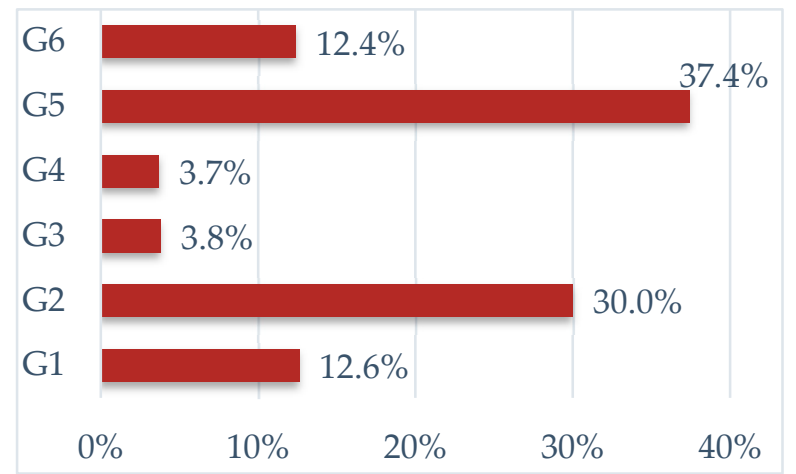

(a)



(b)

Figure 12. Scenario $4-\mathrm{G}_{5}$; (a) the significance of the individual criteria; (b) final ranking.

Finally, the significance of the $\mathrm{G}_{6}$ - ecological criterion was increased. The adopted significance levels for individual criteria are presented in Figure 13a, while the final ranking is presented in Figure $13 \mathrm{~b}$. The change in the significance of the $\mathrm{G}_{6}$ criterion by about 20 percentage points also did not change the ranking. The advantage of variant $A_{1}$ is 10 percentage points over the next alternative, $A_{2}$.

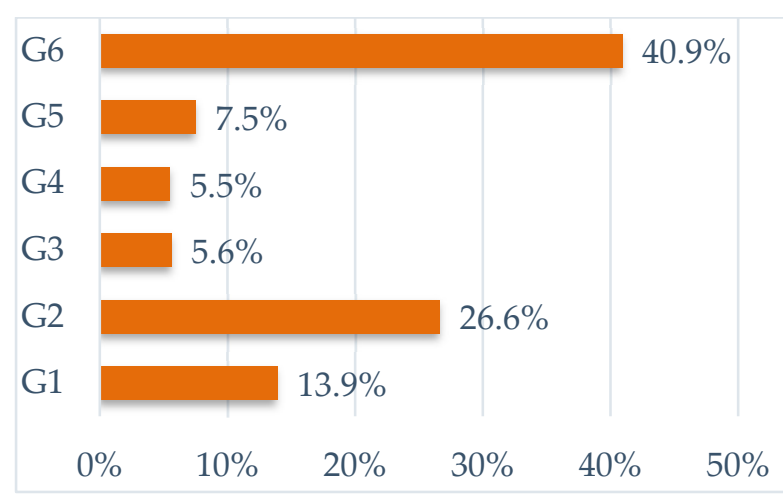

(a)

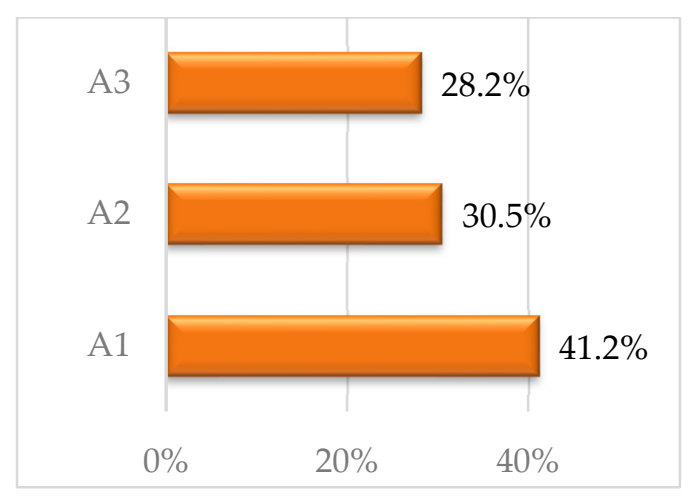

(b)

Figure 13. Scenario $5-\mathrm{G}_{6}$; (a) the significance of the individual criteria; (b) final ranking. 
The results of the sensitivity analysis indicate that the ranking of alternatives remains stable regardless of the adopted significance of the main criteria. Taking into account the results of the AHP analysis and the sensitivity analysis, the variant $\mathrm{A}_{1}$ was adopted as the most appropriate.

\subsection{Fuzzy AHP}

Developing a pairwise comparison matrix can be troublesome in some cases. This may be due to the fact that some information necessary in the decision-making process can be imprecise or unknown. Another factor affecting each decision-making process, and consequently its final ranking, may be the difficulty in describing preferences correctly by decision-makers or experts, in relation to the pairs of compared objects. When it is problematic to determine a pairwise comparison matrix, it is advisable to use fuzzy AHP methodology [32,45]. Therefore, the authors also performed an analysis with Fuzzy AHP. The initial matrices of pairwise comparisons were adopted as the basis for further considerations (Tables 6-12). First, the tables were subject to fuzzification according to Table 4 . 7 fuzzy pairwise comparison matrices were obtained (Tables 17-23), and the fuzzification factor $\Delta=1$ was adopted.

Table 17. Fuzzy pairwise comparison matrix for criteria $G_{1}-G_{6}$.

\begin{tabular}{ccccccc}
\hline & $\mathrm{G}_{\mathbf{1}}$ & $\mathrm{G}_{\mathbf{2}}$ & $\mathrm{G}_{\mathbf{3}}$ & $\mathrm{G}_{\mathbf{4}}$ & $\mathrm{G}_{5}$ & $\mathrm{G}_{\mathbf{6}}$ \\
\hline $\mathrm{G}_{1}$ & $(1 ; 1 ; 1)$ & $(1 / 5 ; 1 / 4 ; 1 / 3)$ & $(4 ; 5 ; 6)$ & $(4 ; 5 ; 6)$ & $(1 / 2 ; 1 ; 2)$ & $(1 / 2 ; 1 ; 2)$ \\
$\mathrm{G}_{2}$ & $(3 ; 4 ; 5)$ & $(1 ; 1 ; 1)$ & $(4 ; 5 ; 6)$ & $(3 ; 4 ; 5)$ & $(3 ; 4 ; 5)$ & $(2 ; 3 ; 4)$ \\
$\mathrm{G}_{3}$ & $(1 / 6 ; 1 / 5 ; 1 / 4)$ & $(1 / 6 ; 1 / 5 ; 1 / 4)$ & $(1 ; 1 ; 1)$ & $(1 / 2 ; 1 ; 2)$ & $(1 / 2 ; 1 ; 2)$ & $(1 / 5 ; 1 / 4 ; 1 / 3)$ \\
$\mathrm{G}_{4}$ & $(1 / 6 ; 1 / 5 ; 1 / 4)$ & $(1 / 5 ; 1 / 4 ; 1 / 3)$ & $(1 / 2 ; 1 ; 2)$ & $(1 ; 1 ; 1)$ & $(1 / 2 ; 1 ; 2)$ & $(1 / 6 ; 1 / 5 ; 1 / 4)$ \\
$\mathrm{G}_{5}$ & $(1 / 2 ; 1 ; 2)$ & $(1 / 5 ; 1 / 4 ; 1 / 3)$ & $(1 / 2 ; 1 ; 2)$ & $(1 / 2 ; 1 ; 2)$ & $(1 ; 1 ; 1)$ & $(1 / 5 ; 1 / 4 ; 1 / 3)$ \\
$\mathrm{G}_{6}$ & $(1 / 2 ; 1 ; 2)$ & $(1 / 4 ; 1 / 3 ; 1 / 2)$ & $(3 ; 4 ; 5)$ & $(4 ; 5 ; 6)$ & $(3 ; 4 ; 5)$ & $(1 ; 1 ; 1)$ \\
\hline
\end{tabular}

Table 18. Fuzzy pairwise comparison matrix for criteria K1-K4.

\begin{tabular}{ccccc}
\hline & K1 & K2 & K3 & K4 \\
\hline K1 & $(1 ; 1 ; 1)$ & $(1 / 8 ; 1 / 7 ; 1 / 6)$ & $(1 / 2 ; 1 ; 2)$ & $(1 / 8 ; 1 / 7 ; 1 / 6)$ \\
K2 & $(6 ; 7 ; 8)$ & $(1 ; 1 ; 1)$ & $(4 ; 5 ; 6)$ & $(1 / 2 ; 1 ; 2)$ \\
K3 & $(1 / 2 ; 1 ; 2)$ & $(1 / 6 ; 1 / 5 ; 1 / 4)$ & $(1 ; 1 ; 1)$ & $(1 / 4 ; 1 / 3 ; 1 / 2)$ \\
K4 & $(6 ; 7 ; 8)$ & $(1 / 2 ; 1 ; 2)$ & $(2 ; 3 ; 4)$ & $(1 ; 1 ; 1)$ \\
\hline
\end{tabular}

Table 19. Fuzzy pairwise comparison matrix for criteria K5-K8.

\begin{tabular}{ccccc}
\hline & K5 & K6 & K7 & K8 \\
\hline K5 & $(1 ; 1 ; 1)$ & $(1 / 6 ; 1 / 5 ; 1 / 4)$ & $(1 / 6 ; 1 / 5 ; 1 / 4)$ & $(1 / 4 ; 1 / 3 ; 1 / 2)$ \\
K6 & $(4 ; 5 ; 6)$ & $(1 ; 1 ; 1)$ & $(1 / 2 ; 1 ; 2)$ & $(1 / 3 ; 1 / 2 ; 1)$ \\
K7 & $(4 ; 5 ; 6)$ & $(1 / 2 ; 1 ; 2)$ & $(1 ; 1 ; 1)$ & $(1 / 3 ; 1 / 2 ; 1)$ \\
K8 & $(2 ; 3 ; 4)$ & $(1 ; 2 ; 3)$ & $(1 ; 2 ; 3)$ & $(1 ; 1 ; 1)$ \\
\hline
\end{tabular}

Table 20. Fuzzy pairwise comparison matrix for criteria K9-K11.

\begin{tabular}{cccc}
\hline & K9 & K10 & K11 \\
\hline K9 & $(1 ; 1 ; 1)$ & $(1 / 2 ; 1 ; 2)$ & $(1 / 4 ; 1 / 3 ; 1 / 2)$ \\
K10 & $(1 / 2 ; 1 ; 2)$ & $(1 ; 1 ; 1)$ & $(1 / 5 ; 1 / 4 ; 1 / 3)$ \\
K11 & $(2 ; 3 ; 4)$ & $(3 ; 4 ; 5)$ & $(1 ; 1 ; 1)$ \\
\hline
\end{tabular}


Table 21. Fuzzy pairwise comparison matrix for criteria K12-K15.

\begin{tabular}{ccccc}
\hline & K12 & K13 & K14 & K15 \\
\hline K12 & $(1 ; 1 ; 1)$ & $(1 / 2 ; 1 ; 2)$ & $(1 ; 2 ; 3)$ & $(1 ; 2 ; 3)$ \\
K13 & $(1 / 2 ; 1 ; 2)$ & $(1 ; 1 ; 1)$ & $(2 ; 3 ; 4)$ & $(4 ; 5 ; 6)$ \\
K14 & $(1 / 3 ; 1 / 2 ; 1)$ & $(1 / 4 ; 1 / 3 ; 1 / 2)$ & $(1 ; 1 ; 1)$ & $(1 / 2 ; 1 ; 2)$ \\
K15 & $(1 / 3 ; 1 / 2 ; 1)$ & $(1 / 6 ; 1 / 5 ; 1 / 4)$ & $(1 / 2 ; 1 ; 2)$ & $(1 ; 1 ; 1)$ \\
\hline
\end{tabular}

Table 22. Fuzzy pairwise comparison matrix for criteria K16-K21.

\begin{tabular}{ccccccc}
\hline & K16 & K17 & K18 & K19 & K20 & K21 \\
\hline K16 & $(1 ; 1 ; 1)$ & $(1 / 5 ; 1 / 4 ; 1 / 3)$ & $(1 / 2 ; 1 ; 2)$ & $(1 / 4 ; 1 / 3 ; 1 / 2)$ & $(1 / 4 ; 1 / 3 ; 1 / 2)$ & $(1 / 2 ; 1 ; 2)$ \\
K17 & $(3 ; 4 ; 5)$ & $(1 ; 1 ; 1)$ & $(4 ; 5 ; 6)$ & $(2 ; 3 ; 4)$ & $(2 ; 3 ; 4)$ & $(2 ; 3 ; 4)$ \\
K18 & $(1 / 2 ; 1 ; 2)$ & $(1 / 6 ; 1 / 5 ; 1 / 4)$ & $(1 ; 1 ; 1)$ & $(1 / 3 ; 1 / 2 ; 1)$ & $(1 / 4 ; 1 / 3 ; 1 / 2)$ & $(2 ; 3 ; 4)$ \\
K19 & $(2 ; 3 ; 4)$ & $(1 / 4 ; 1 / 3 ; 1 / 2)$ & $(1 ; 2 ; 3)$ & $(1 ; 1 ; 1)$ & $(1 / 4 ; 1 / 3 ; 1 / 2)$ & $(1 / 2 ; 1 ; 2)$ \\
K20 & $(2 ; 3 ; 4)$ & $(1 / 4 ; 1 / 3 ; 1 / 2)$ & $(2 ; 3 ; 4)$ & $(2 ; 3 ; 4)$ & $(1 ; 1 ; 1)$ & $(2 ; 3 ; 4)$ \\
K21 & $(1 / 2 ; 1 ; 2)$ & $(1 / 4 ; 1 / 3 ; 1 / 2)$ & $(1 / 4 ; 1 / 3 ; 1 / 2)$ & $(1 / 2 ; 1 ; 2)$ & $(1 / 4 ; 1 / 3 ; 1 / 2)$ & $(1 ; 1 ; 1)$ \\
\hline
\end{tabular}

Table 23. Fuzzy pairwise comparison matrix for criteria K22-K25.

\begin{tabular}{ccccc}
\hline & K22 & K23 & K24 & K25 \\
\hline K22 & $(1 ; 1 ; 1)$ & $(1 / 2 ; 1 ; 2)$ & $(1 / 2 ; 1 ; 2)$ & $(1 / 3 ; 1 / 2 ; 1)$ \\
K23 & $(1 / 2 ; 1 ; 2)$ & $(1 ; 1 ; 1)$ & $(1 / 2 ; 1 ; 2)$ & $(1 / 2 ; 1 ; 2)$ \\
K24 & $(1 / 2 ; 1 ; 2)$ & $(1 / 2 ; 1 ; 2)$ & $(1 ; 1 ; 1)$ & $(1 / 2 ; 1 ; 2)$ \\
K25 & $(1 ; 2 ; 3)$ & $(1 / 2 ; 1 ; 2)$ & $(1 / 2 ; 1 ; 2)$ & $(1 ; 1 ; 1)$ \\
\hline
\end{tabular}

The analyses used the Fuzzy AHP package for R for fuzzification of pairwise comparison matrix and determination of local weight vectors $\widetilde{w}_{i}=\left(w_{i 1}, w_{i 2}, w_{i 3}\right)$. Local weight vectors for fuzzy numbers were determined using Equations (7)-(9). Global weight vectors $\widetilde{u}_{k}=\left(u_{k 1}, u_{k 2}, u_{k 3}\right)$ (Table 24) were determined in accordance with Equations (10)-(12). It should be noted that the obtained weight vector for middle fuzzy numbers coincides with the weight vector for clean/standard AHP methodology. Next, the weights were subject to defuzzification according to Formula (6), obtaining the final vector of weights (Table 24). The final ranking (Table 25) was determined in accordance with Equation (13).

Table 24. Fuzzy weights for criteria K1-K25.

\begin{tabular}{|c|c|c|c|c|c|c|c|c|c|c|c|c|c|}
\hline & K1 & K2 & K3 & K4 & K5 & K6 & K7 & K8 & K9 & K10 & K11 & K12 & \\
\hline fnMin * & 0.62 & 3.98 & 0.78 & 3.46 & 1.81 & 5.74 & 5.74 & 8.16 & 0.51 & 0.47 & 2.18 & 0.70 & \\
\hline fnModal * & 1.21 & 7.77 & 1.62 & 6.84 & 2.91 & 10.76 & 10.76 & 15.92 & 1.14 & 1.04 & 3.78 & 1.84 & \\
\hline fnMax * & 2.22 & 13.81 & 3.33 & 12.22 & 4.29 & 18.41 & 18.41 & 22.45 & 2.61 & 2.31 & 6.04 & 3.88 & \\
\hline \multirow[t]{2}{*}{$\mathrm{dfnW} W^{*}$} & 1.35 & 8.52 & 1.91 & 7.50 & 3.00 & 11.64 & 11.64 & 15.51 & 1.42 & 1.28 & 4.00 & 2.14 & \\
\hline & K13 & K14 & K15 & K16 & K17 & K18 & K19 & K20 & K21 & K22 & $\mathrm{K} 23$ & K24 & K25 \\
\hline fnMin & 1.22 & 0.37 & 0.33 & 0.24 & 1.52 & 0.32 & 0.42 & 0.85 & 0.26 & 1.91 & 2.13 & 2.13 & 2.60 \\
\hline fnModal & 2.56 & 0.83 & 0.73 & 0.61 & 3.15 & 0.75 & 1.03 & 1.91 & 0.64 & 4.63 & 5.51 & 5.51 & 6.55 \\
\hline fnMax & 4.78 & 1.98 & 1.68 & 1.57 & 5.88 & 1.82 & 2.41 & 3.93 & 1.63 & 10.19 & 11.89 & 11.89 & 12.73 \\
\hline dfnW & 2.85 & 1.06 & 0.91 & 0.81 & 3.52 & 0.97 & 1.29 & 2.23 & 0.84 & 5.58 & 6.51 & 6.51 & 7.29 \\
\hline
\end{tabular}

* fnMin-fuzzy weights for low fuzzy numbers $u_{\mathrm{k} 1}$, fnModal-fuzzy weights for middle fuzzy numbers $u_{\mathrm{k} 2}$, fnMax-fuzzy weights for upper fuzzy numbers $u_{\mathrm{k} 3}, \mathrm{dfnW}$-vector of weights used to calculate the final rating of fuzzy AHP. 
Table 25. Summary of the results of fuzzy AHP for individual variants $A_{1}-A_{3}$.

\begin{tabular}{cccc}
\hline & $\mathbf{A}_{\mathbf{1}}$ & $\mathbf{A}_{\mathbf{2}}$ & $\mathbf{A}_{\mathbf{3}}$ \\
\cline { 2 - 4 } Polder & $\mathbf{4 4 . 2 2}$ & $\mathbf{3 4 . 8 7}$ & $\mathbf{3 1 . 1 8}$ \\
\hline $\mathrm{G}_{1}$ & 10.55 & 5.21 & 3.52 \\
$\mathrm{~K} 1$ & 0.74 & 0.37 & 0.25 \\
$\mathrm{~K} 2$ & 5.11 & 1.70 & 1.70 \\
$\mathrm{~K} 3$ & 0.96 & 0.64 & 0.32 \\
$\mathrm{~K} 4$ & 3.75 & 2.50 & 1.25 \\
$\mathrm{G}_{2}$ & 13.11 & 15.06 & 13.62 \\
$\mathrm{~K} 5$ & 0.50 & 1.00 & 1.50 \\
$\mathrm{~K} 6$ & 2.91 & 4.36 & 4.36 \\
$\mathrm{~K} 7$ & 1.94 & 5.82 & 3.88 \\
$\mathrm{~K} 8$ & 7.76 & 3.88 & 3.88 \\
$\mathrm{G} 3$ & 3.35 & 1.67 & 1.67 \\
$\mathrm{~K} 9$ & 0.71 & 0.36 & 0.36 \\
$\mathrm{~K} 10$ & 0.64 & 0.32 & 0.32 \\
$\mathrm{~K} 11$ & 2.00 & 1.00 & 1.00 \\
$\mathrm{G}_{4}$ & 2.63 & 2.35 & 1.99 \\
$\mathrm{~K} 12$ & 1.07 & 0.71 & 0.36 \\
$\mathrm{~K} 13$ & 0.57 & 1.14 & 1.14 \\
$\mathrm{~K} 14$ & 0.53 & 0.26 & 0.26 \\
$\mathrm{~K} 15$ & 0.46 & 0.23 & 0.23 \\
$\mathrm{G} 5$ & 3.31 & 3.27 & 3.07 \\
$\mathrm{~K} 16$ & 0.81 & 0.00 & 0.00 \\
$\mathrm{~K} 17$ & 0.00 & 1.76 & 1.76 \\
$\mathrm{~K} 18$ & 0.00 & 0.48 & 0.48 \\
$\mathrm{~K} 19$ & 1.29 & 0.00 & 0.00 \\
$\mathrm{~K} 20$ & 1.22 & 0.61 & 0.41 \\
$\mathrm{~K} 21$ & 0.00 & 0.42 & 0.42 \\
$\mathrm{G} 6$ & 11.27 & 7.31 & 7.31 \\
$\mathrm{~K} 22$ & 1.12 & 2.23 & 2.23 \\
$\mathrm{~K} 23$ & 3.25 & 1.63 & 1.63 \\
$\mathrm{~K} 24$ & 3.25 & 1.63 & 1.63 \\
$\mathrm{~K} 25$ & 3.65 & 1.82 & 1.82 \\
\hline & & & \\
& &
\end{tabular}

The same final ranking $\mathrm{A}_{1} \rightarrow \mathrm{A}_{2} \rightarrow \mathrm{A}_{3}$ was obtained as in the case of standard AHP methodology. As before, safety issues $\left(G_{2}\right)$ in each of the analysed variants were similar, reaching the level of approximately $13-15 \%$. Variant $A_{1}$ gained a decisive advantage with regard to social criteria $\left(\mathrm{G}_{1}\right)$ (more than twofold over the other alternatives) and ecological criteria $\left(\mathrm{G}_{6}\right)$ (almost twofold).

\section{Discussion}

This study focuses on choosing an optimal method for adapting the area, which is currently periodically flooded, but does not have the formal status of a polder as an element of the flood protection system. The analyses took into account the problems related to the modification of the current land development, i.e., agricultural use, farming, cultural heritage, ecological issues. The application of Multi-Criteria Decision-making methodology made it possible to select the best solution. The final ratings of standard AHP and fuzzy AHP indicate Variant $\mathrm{A}_{1}$ as the most favourable. These methods can also be used to plan the optimal operation of a cluster of polders, compare the work by [46]. The AHP method should also be supplemented with a sensitivity analysis. The conducted analysis indicates the stability of the final ranking obtained, regardless of the adopted significance of the individual main criteria. The analyses presented in the work are not only theoretical, but can also be used in engineering practice. The variant of polder modernization selected in the ranking is possible to implement in accordance with the law in force in Poland. 
Komi et al. [5], using AHP, by analysing and identifying the main factors contributing to flood risk of rural communities in the Oti basin of Togo, indicated that reducing vulnerability by creating new income generation opportunities and increasing the community's ability to manage its own flood risk should be paramount to reducing flood risk in the subject area. Variant $\mathrm{A}_{1}$, which assumes the maintaining of the current legal status of the polder area but ensuring coverage of flood losses by the state and insurance companies, increases the ability of the local community to manage its own flood risk. A well-designed national risk management strategy should first rely on risk analysis and risk quantification and establish a legal and institutional framework for disaster management. It should contain appropriate financing instruments, including reinsurance, provide liquidity immediately after the occurrence of a natural disaster, deliver disaster insurance pools and other risk aggregation mechanisms, as well as incentives for the private insurance sector to efficiently and effectively distribute the insurance product [47].

In the case of difficulties with developing a pairwise comparison matrix, i.e., linked to the determination of explicitly stated, clearly defined preference values by experts or decision-makers, the theory of fuzzy sets and Fuzzy AHP can be successfully applied [48], making evaluation results more reasonable and comprehensive [49]. The parameterization of models related to flood risk management is associated with numerous uncertainties related to, i.a., imprecise data and problems with the correct development of the pairwise comparison matrix. Analyses should take into account not only the economic aspects of investments, but also other values, often difficult to measure or define, for instance the values of natural resources, in order to fully evaluate a given project [50]. These inaccuracies and uncertainties can be included in the model by introducing fuzzy numbers and fuzzy AHP. This finds confirmation in the work by Shumann and Nijsen [6], who compared the use of fuzzy AHP and fuzzy TOPSIS in flood polder planning methods. The researchers indicate that, despite some differences in application, both methods with common goals are similar and the tools they offer should definitely be used in Decision Support System (DSS). Fuzzy AHP can be considered flexible and reliable for assessing water management plans [51], also under conditions of uncertainty [52].

\section{Conclusions}

The modernization or construction of large-scale hydrotechnical facilities such as polders will always require an analysis that takes into account many aspects, from purely technical, through economic and environmental, to social. The polder is a retention reservoir during the flood wave, and on the other hand, it is often an agricultural and economic area. In many European countries, polder sites are inhabited by local communities who have become accustomed to periodic floods and have knowledge of how to deal with them. Over the centuries, they have created valuable objects and landscapes of a unique character, which may be liquidated after a change in the way the area is managed. When planning the construction or modernization of such facilities, it is absolutely necessary to conduct the most objective, quantitative and qualitative analyses of the effectiveness of such an investment. In the case of flood protection facilities, the element determining the decision on investment is the technical factor related to increasing the effectiveness of flood protection of the areas below the facility. Local communities usually read this as "sacrificing" their welfare to a community with which they are not related. The analysis presented in the paper showed that taking into account a wide range of factors may objectively demonstrate the lack of purposefulness of such an investment and the preservation of the existing state of development.

Author Contributions: Conceptualization, I.L.; methodology, Z.W. and I.L.; validation, I.L. and Z.W.; formal analysis, Z.W. and I.L.; investigation, I.L. and Z.W.; resources, I.L. and Z.W.; data curation, I.L. and Z.W.; writing-original draft preparation, I.L. and Z.W.; writing-review and editing, I.L. and Z.W.; visualization, I.L. and Z.W. All authors have read and agreed to the published version of the manuscript.

Funding: This research received no external funding.

Conflicts of Interest: The authors declare no conflict of interest. 


\section{References}

1. Kumar, A.; Sah, B.; Singh, A.R.; Deng, Y.; He, X.; Kumar, P.; Bansal, R.C. A review of multi criteria decision making (MCDM) towards sustainable renewable energy development. Renew. Sustain. Energy Rev. 2017, 69, 596-609. [CrossRef]

2. Mulliner, E.; Malys, N.; Maliene, V. Comparative analysis of MCDM methods for the assessment of sustainable housing affordability. Omega 2016, 59, 146-156. [CrossRef]

3. Saaty, T.L. Decision making with the analytic hierarchy process. Int. J. Serv. Sci. 2008, 1, 83-98. [CrossRef]

4. Siddayao, G.P.; Valdez, S.E.; Fernandez, P.L. Analytic hierarchy process (AHP) in spatial modeling for floodplain risk assessment. Int. J. Mach. Learn. Comput. 2014, 4, 450. [CrossRef]

5. Komi, K.; Amisigo, B.; Diekkrüger, B. Integrated Flood Risk Assessment of Rural Communities in the Oti River Basin, West Africa. Hydrology 2016, 3, 42. [CrossRef]

6. Schumann, A.H.; Nijssen, D. Application of scenarios and multi-criteria decision making tools in flood polder planning. In Flood Risk Assessment and Management; Springer: Berlin/Heidelberg, Germany, 2011; pp. 249-275.

7. Sinha, R.; Bapalu, G.V.; Singh, L.K.; Rath, B. Flood risk analysis in the Kosi river basin, north Bihar using multi-parametric approach of analytical hierarchy process (AHP). J. Indian Soc. Remote Sens. 2008, 36, 335-349. [CrossRef]

8. Stefanidis, S.; Stathis, D. Assessment of flood hazard based on natural and anthropogenic factors using analytic hierarchy process (AHP). Nat. Hazards 2013, 68, 569-585. [CrossRef]

9. Suseno, D.A.; Sunarto, S. Strategi Kebijakan Pengelolaan Polder Tawang Sebagai Pengendali Banjir Dengan Pendekatan Analysis Hierarchy Process (AHP). JEJAK J. Ekon. Dan Kebijak. 2012, 569-585.

10. Cabrera, J.; Lee, H.S. Flood-Prone Area Assessment Using GIS-Based Multi-Criteria Analysis: A Case Study in Davao Oriental, Philippines. Water 2019, 11, 2203. [CrossRef]

11. Abdelkarim, A.; Al-Alola, S.S.; Alogayell, H.M.; Mohamed, S.A.; Alkadi, I.I.; Ismail, I.Y. Integration of GIS-Based Multicriteria Decision Analysis and Analytic Hierarchy Process to Assess Flood Hazard on the Al-Shamal Train Pathway in Al-Qurayyat Region, Kingdom of Saudi Arabia. Water 2020, 12, 1702. [CrossRef]

12. Njiru, F.M. Hydrological Information for Dam Site Selection by Integrating Geographic Information System (GIS) and Analytical Hierarchical Process (AHP). Ph.D. Thesis, University of Nairobi, Nairobi, Kenya, 2017.

13. Vogel, R. Methodology and software solutions for multicriteria evaluation of floodplain retention suitability. Cartogr. Geogr. Inf. Sci. 2016, 43, 301-320. [CrossRef]

14. Demirel, T.; Demirel, N.Ç.; Kahraman, C. Fuzzy analytic hierarchy process and its application. In Fuzzy Multi-Criteria Decision Making; Springer: Berlin/Heidelberg, Germany, 2008; pp. 53-83.

15. Patil, A.N. Fuzzy ahp methodology and its sole applications. Int. J. Manag. Res. Rev. 2018, 8, $24-32$.

16. Kahraman, C.; Cebeci, U.; Ulukan, Z. MultiMulti Mul supplier selection using fuzzy AHP. Logist. Inf. Manag. 2003, 16, 382-394. [CrossRef]

17. Van Laarhoven, P.J.M.; Pedrycz, W. A fuzzy extension of Saaty's priority theory. Fuzzy Sets Syst. 1983, 11, 229-241. [CrossRef]

18. Buckley, J.J.; Uppuluri, V.R.R. Fuzzy hierarchical analysis. In Uncertainty in Risk Assessment, Risk Management, and Decision Making; Springer: Berlin/Heidelberg, Germany, 1987; pp. 389-401.

19. Gündoğdu, F.K.; Kahraman, C. A novel spherical fuzzy analytic hierarchy process and its renewable energy application. Soft Comput. 2020, 24, 4607-4621. [CrossRef]

20. Balusa, B.C.; Gorai, A.K. Sensitivity analysis of fuzzy-analytic hierarchical process (FAHP) decision-making model in selection of underground metal mining method. J. Sustain. Min. 2019, 18, 8-17. [CrossRef]

21. Laks, I. Wpływ retencji polderu Golina na transformację fali powodziowej z 2010 r. Gospod. Wodna 2017, 2, 49-57.

22. Ardıçlıoğlu, M.; Kuriqi, A. Calibration of channel roughness in intermittent rivers using HEC-RAS model: Case of Sarimsakli creek, Turkey. SN Appl. Sci. 2019, 1, 1080. [CrossRef]

23. Kuriqi, A.; Ali, R.; Pham, Q.B.; Gambini, J.M.; Gupta, V.; Malik, A.; Linh, N.T.T.; Joshi, Y.; Anh, D.T.; Dong, X. Seasonality shift and streamflow flow variability trends in central India. Acta Geophys. 2020, 1-15. [CrossRef] 
24. Juez, C.; Schärer, C.; Jenny, H.; Schleiss, A.J.; Franca, M.J. Floodplain Land Cover and Flow Hydrodynamic Control of Overbank Sedimentation in Compound Channel Flows. Water Resour. Res. 2019, 55, 9072-9091. [CrossRef]

25. Głuszak, J. Jeziorsko-geneza i koncepcja zbiornika. Gospod. Wodna 1986, 8, 183-184.

26. Chodyła, Z. Zarys Najstarszych Dziejów Osad Olęderskich w Puszczy Pyzdrskiej 1746-1793; Lokalna Organizacja Turystyczna "Puszcza Pyzdrska": Pyzdry, Poland, 2015.

27. Saaty, T.L. Decision making—The analytic hierarchy and network processes (AHP/ANP). J. Syst. Sci. Syst. Eng. 2004, 13, 1-35. [CrossRef]

28. Saaty, T.L. How to make a decision: The analytic hierarchy process. Eur. J. Oper. Res. 1990, 48, 9-26. [CrossRef]

29. Saaty, R.W. The analytic hierarchy process-what it is and how it is used. Math. Model. 1987, 9, 161-176. [CrossRef]

30. Glur, C.; Glur, M.C. Package 'ahp'. Elérhető. 2018. Available online: https://cran.r-project.org/package=ahp (accessed on 29 September 2020).

31. Saaty, T.L. Decision Making for Leaders: The Analytic Hierarchy Process for Decisions in a Complex World; RWS Publications: Pittsburgh, PA, USA, 1990; ISBN 1888603135.

32. Krejčí, J.; Pavlačka, O.; Talašová, J. A fuzzy extension of Analytic Hierarchy Process based on the constrained fuzzy arithmetic. Fuzzy Optim. Decis. Mak. 2017, 16, 89-110. [CrossRef]

33. Tesfamariam, S.; Sadiq, R. Risk-based environmental decision-making using fuzzy analytic hierarchy process (F-AHP). Stoch. Environ. Res. Risk Assess. 2006, 21, 35-50. [CrossRef]

34. Chou, Y.-C.; Yen, H.-Y.; van Dang, T.; Sun, C.-C. Assessing the human resource in science and technology for Asian countries: Application of fuzzy AHP and fuzzy TOPSIS. Symmetry 2019, 11, 251. [CrossRef]

35. Güngör, Z.; Serhadlığlu, G.; Kesen, S.E. A fuzzy AHP approach to personnel selection problem. Appl. Soft Comput. 2009, 9, 641-646. [CrossRef]

36. Tiryaki, F.; Ahlatcioglu, B. Fuzzy portfolio selection using fuzzy analytic hierarchy process. Inf. Sci. 2009, 179, 53-69. [CrossRef]

37. Halim, F.A.; Azman, A.; Malim, M.R. Prioritising Critical Success Factors of TQM in Malaysia Aerospace Industry Using Fuzzy AHP. In Journal of Physics: Conference Series; Halim, F.A., Azman, A., Malim, M.R., Eds.; IOP Publishing: Bristol, UK, 2019.

38. Chen, S.-M. Evaluating weapon systems using fuzzy arithmetic operations. Fuzzy Sets Syst. 1996, 77, $265-276$. [CrossRef]

39. Kutlu, A.C.; Ekmekçioğlu, M. Fuzzy failure modes and effects analysis by using fuzzy TOPSIS-based fuzzy AHP. Expert Syst. Appl. 2012, 39, 61-67. [CrossRef]

40. Chen, S.-H. Ranking fuzzy numbers with maximizing set and minimizing set. Fuzzy Sets Syst. 1985, 17, 113-129. [CrossRef]

41. Hamidi, J.K.; Shahriar, K.; Rezai, B.; Rostami, J.; Bejari, H. Risk assessment based selection of rock TBM for adverse geological conditions using Fuzzy-AHP. Bull. Eng. Geol. Environ. 2010, 69, 523-532. [CrossRef]

42. Yager, R.R.; Yager, R. On a general class of fuzzy connectives. Fuzzy Sets Syst. 1980, 4, 235-242. [CrossRef]

43. Enea, M.; Piazza, T. Project selection by constrained fuzzy AHP. Fuzzy Optim. Decis. Mak. 2004, 3, $39-62$. [CrossRef]

44. Caha, J.; Drážná, A. Information about FuzzyAHP Package for R (ver.0.9.5); CRAN: Perth, ON, Canada, 2019.

45. Wang, Y.-M.; Luo, Y.; Hua, Z. On the extent analysis method for fuzzy AHP and its applications. Eur. J. Oper. Res. 2008, 186, 735-747. [CrossRef]

46. Pratiwi, M.A.N.; Nuraini, N.; Nugroho, H.; Kurniani, D. Kajian Kinerja Sistem Polder Dengan Balance Scorecard. J. Karya Tek. Sipil 2016, 5, 79-89.

47. Lester, R.; Gurenko, E. Rapid Onset Natural Disasters: The Role of Financing in Effective Risk Management; The World Bank: Washington, DC, USA, 2004.

48. Zou, Q.; Zhou, J.; Zhou, C.; Song, L.; Guo, J. Comprehensive flood risk assessment based on set pair analysis-variable fuzzy sets model and fuzzy AHP. Stoch. Environ. Res. Risk Assess. 2013, 27, 525-546. [CrossRef] 
49. Yang, X.-L.; Ding, J.-H.; Hou, H. Application of a triangular fuzzy AHP approach for flood risk evaluation and response measures analysis. Nat. Hazards 2013, 68, 657-674. [CrossRef]

50. Liziński, T.; Wróblewska, A.; Rauba, K. Application of CVM method in the evaluation of flood control and water and sewage management projects. J. Water Land Dev. 2015, 24, 41-49. [CrossRef]

51. Srdjevic, B.; Medeiros, Y.D.P. Fuzzy AHP assessment of water management plans. Water Resour. Manag. 2008, 22, 877-894. [CrossRef]

52. Bender, M.J.; Simonovic, S.P. A fuzzy compromise approach to water resource systems planning under uncertainty. Fuzzy Sets Syst. 2000, 115, 35-44. [CrossRef]

(C) 2020 by the authors. Licensee MDPI, Basel, Switzerland. This article is an open access article distributed under the terms and conditions of the Creative Commons Attribution (CC BY) license (http://creativecommons.org/licenses/by/4.0/). 